\title{
Whether China's State-Owned Commercial Banks Constitute "Public Bodies" within the Meaning of Article 1.1 (a) (1) of the Agreement on Subsidies and Countervailing Measures: Analysis of US-Definitive Anti-Dumping and Countervailing Duties on Certain Products from China
}

\author{
Yi Liao \\ Faculty of Law, University of Toronto, Toronto, Canada \\ Email: roxyliao1988@gmail.com
}

Received September $24^{\text {th }}, 2013$; revised October $26^{\text {th }}, 2013$; accepted November $23^{\text {rd }}, 2013$

\begin{abstract}
Copyright (C) 2013 Yi Liao. This is an open access article distributed under the Creative Commons Attribution License, which permits unrestricted use, distribution, and reproduction in any medium, provided the original work is properly cited.
\end{abstract}

\begin{abstract}
US-Definitive Anti-Dumping and Countervailing Duties on Certain Products from China is the initial WTO dispute in which China claims that US-countervailing duties on certain products from China are inconsistent with the obligations of the United States under the Agreement on Subsidies and Countervailing Measures ("SCM Agreement"). In this dispute, the specific meaning of "public bodies" within Article 1.1 (a) (1) of the SCM Agreement and the question of whether China's state-owned commercial banks ("SOCB") constitute "public bodies" are the heart of the matter. This thesis will analyze these issues by examining the reports of the Panel and the Appellate Body. In particular, the thesis will argue that the theory of the governmental function advanced by China is much more persuasive than that of governmental control in terms of defining "public bodies". Although China's SOCBs have gone through several stages of reforms, the majority ownership of them has remained in the hands of the Chinese government. However, SOCBs' policy-oriented nature has been largely marginalized, and currently they only perform subsidiary governmental functions. In this regard, the conclusion this thesis will attempt to reach is that the WTO system needs to give developing countries like China more policy flexibility in order to upgrade their international trade participation to the level required and followed by developed countries. During the process, developing countries should also make the best use of their latent comparative advantage and the effects of globalization.
\end{abstract}

Keywords: Public Bodies; State-Owned Commercial Banks

\section{Introduction}

China put banking reform on its agenda in 1978 with the goal of modifying the structure of its banking system. Over the past three decades, China's banking sector has evolved from a mono-bank system, in which the People's Bank of China ("PBOC") served the dual roles of central bank and sole commercial bank, into "an increasingly sophisticated and open system with multiple institutions performing diverse financial functions" (Chen, 2012). In this system, large state-owned commercial banks are playing a crucial and dominant role.

In 2001, China's entry into the World Trade Organization ("WTO") was conditioned on its reduction of over 7000 tariffs quotas and other trade barriers, including opening its market to foreign banks within five years. Some Chinese commentators were concerned that foreign competition would overturn inefficient state-owned enterprises ("SOEs"), as to some it did. But China, overall, has enjoyed one of the best decades in global economic history, with a remarkable increase in its GDP and exports ("China's Economy", 2011). Despite its economic suc- cess, Chinese scholar Yongtu Long, who helped China win admission to the WTO, is concerned that China's economic philosophy has seldom changed, and it is now moving further away from the WTO's principles. To modernize its economy, China has remained wedded to industrial policies, SOEs, and a "technonationalism" that protects and promotes homegrown technologies ("China's Economy", 2011). Many foreign companies feel they must compete with the Chinese state instead of Chinese firms.

The United States began applying its countervailing duty legislation to imports from China in 2007, after the United States Department of Commerce ("USDOC") determined that China's economy, albeit still not a market economy, had undergone sufficient economic reform as to enable the USDOC to identify and countervail subsidies granted by the Chinese government.

Under the circumstance, US-Definitive Anti-Dumping and Countervailing Duties on Certain Products from China is the initial WTO dispute in which China claims that US-countervailing duties on certain products from China are inconsistent 
with the obligations of the United States under the Agreement on Subsidies and Countervailing Measures ("SCM Agreement"). In this dispute, the specific meaning of "public bodies" within Article 1.1 (a) (1) of the SCM Agreement and the question of whether SOEs and SOCBs in China constitute "public bodies" are the heart of the matter.

Although there are many studies available on SOEs in China in a trade context, there are quite limited studies on SOCBs by scholars either within or outside China; this gap provides a necessity and, in some way, urgency of the proposed study with regard to increasing trade-related disputes in which conflicting interpretations of the status of SOCBs play a crucial role. The hypothesis I will provide at this stage is that the theory of the governmental function advanced by China is much more persuasive than that of governmental control in terms of defining "public bodies" within the meaning of Article 1.1 (a) (1) of the SCM Agreement. Indeed, by either criterion, SOCBs in China could probably be identified as "public bodies". However, the policy-oriented nature of SOCBs has been largely marginalized in the past three decades, and they currently only perform subsidiary governmental functions in line with macro-economic goals; in essence, they are profit-motivated enterprises.

A thorough analysis of the status of China's SOCBs is conducive to providing a better understanding of the similarity and uniqueness of their nature with respect to their counterparts in western countries, thus giving an insightful understanding of China's international trade policies, which are closely related to its banking system and joint-stock reform. In a broader sense, a detailed examination of "public body" within Article 1.1 (a) (1) of the SCM Agreement could help preserve the strength and effectiveness of the subsidy disciplines in the context of international trade, and inhibit circumvention by ensuring that government cannot escape those disciplines by utilizing entities to accomplish tasks that would potentially be subject to those disciplines.

This paper is divided into six sections. The introduction sketches the background, the issue, and the significance of this study. The factual background of the dispute is presented in the second section. Third, various criteria for defining "public body" are outlined, along with detailed evaluation of those criteria. In the fourth section, this paper examines the status of SOCBs in China by means of policy and legal approaches. Based on the discussion of "public bodies", this paper then addresses whether SOCBs lending loans and land-use rights satisfy "specificity" within the meaning of Article 2 and constitute "subsidies" as defined by Article 1 of the SCM Agreement. In the last section, this paper concludes by supporting the theory of governmental function proposed by China, but SOCBs in China could still possibly constitute "public bodies" and their lending loans constitute "subsidies" within the SCM Agreement. In addition, some challenges and recommendations deserving further research are identified.

\section{The Case of US-Definitive Anti-Dumping and Countervailing Duties on Certain Products from China}

On 19 September 2008, China requested consultations concerning the definitive anti-dumping and countervailing duties imposed by the United States as a result of four anti-dumping and countervailing duty investigations conducted by the USDOC, covering four products from China to the United States: 1) Circular Welded Carbon Quality Steel Pipe ("CWP"); 2)
Certain New Pneumatic Off-the-Road Tires ("OTR"); 3) Light-Walled Rectangular Pipe and Tube (“LWR"); and 4) Laminated Woven Sacks ("LWS") (Panel Report, 2011, USAnti-Dumping and Countervailing Duties, para.2.1). China considered that these measures, which included the conduct of the underlying anti-dumping and countervailing duty investigations, were inconsistent with the obligations of the United States under inter alia, Articles I and VI of the General Agreement on Tariffs and Trade 1994 ("GATT 1994") (Agreement on Tarrifs and Trade, 1994), Articles 1, 2, 9, 10, 12, 13, 14, 19 and 32 of the SCM Agreement, Articles 1, 2, 6, 9 and 18 of the Agreement on Implementation of Article VI of the General Agreement on Tariffs and Trade 1994 ("Anti-Dumping Agreement") (Agreement on Implementation of Article VI of the General Agreement on Tariffs and Trade, 1994), and Article 15 of the Protocol on the Accession of the People's Republic of China (Protocol on the Accession of the People's Republic of China, 2001).

With respect to the countervailing duty investigation, the USDOC determined that China provided subsidies in the form of preferential lending by SOCBs to several producers such as Weifang East Steel Pipe Co., Ltd. ("East Pipe"), Guizhou Tire Co., Ltd. ("GTC"), and Heibei Starbright Tire Co., Ltd. ("Starbright"). Those producers exported subsidized goods to the United States, and these subsidies, according to the USCOC, were specific. The USDOC also found that the government provision of land-use rights was a countervailable subsidy.

On 9 December 2008, China requested the establishment of a panel. On 22 October 2010, the panel report was circulated to Members. China appealed certain Panel's findings regarding the USDOC's determinations on "public body", "specificity", "benefit benchmarks", and "double remedies". On 11 March 2011, the Appellate Body report was circulated to Members.

In this dispute, one of the major issues in contention between China and the United States is whether China's SOCBs constitute the "public bodies" within the meaning of Article 1.1 (a) (1) of the SCM Agreement. The Panel interpreted the term "public body" to mean "any entity controlled by a government" (SCM Agreement, 1994). The Panel considered government ownership to be highly relevant and potentially dispositive evidence of government control (SCM Agreement, 1994), and, on that basis, upheld the USDOC's determinations that the SOEs and SOCBs constitute public bodies. The Appellate Body first recalled that while China and the United States advocated different definitions of the term, their respective conceptions of the entities that may properly be considered "public bodies" are not mutually exclusive, and in fact overlap significantly (Appellate Body Report, 2011, US-Anti-Dumping and Countervailing Duties, para.281). The Appellate Body considered that the Panel's interpretation of "public body" lacked a proper legal basis, and therefore reversed its finding by adopting the position that a public body is an entity that "possesses, exercises, or is vested with, governmental authority" (Appellate Body Report, 2011, US-Anti-Dumping and Countervailing Duties, para. 317). However, the Appellate Body affirmed that the USDOC's public body determination in respect of SOCBs was supported by evidence that these SOCBs exercise governmental functions on behalf of the Chinese Government. Therefore, it concluded that SOCBs in China are "controlled by the government and that they effectively exercise certain governmental functions" (Appellate Body Report, 2011, US-Anti-Dumping and Countervailing Duties, para.355). 
Regarding the second issue of "specificity", the Panel agreed with the United States that lending by SOCBs to the tire industry was de jure specific, but it did not agree that the USDOC's determination of regional specificity in respect of the provision of land-use rights to Aifudi was consistent with the obligations of the United States under Article 2 of the SCM Agreement (Panel Report, 2011, US-Anti-Dumping and Countervailing Duties, para.9.161). With respect to SOCBs lending loans, the Appellate Body upheld the Panel's finding that the USDOC acted consistently with the obligation of the United States under Article 2.1 (a) of the SCM Agreement by determining that SOCB lending was specific to the tire industry (Appellate Body Report, 2011, US-Anti-Dumping and Countervailing Duties, para.393). In terms of the land-use rights, China agreed with the Panel's conclusion that the USDOC's determination was inconsistent with Article 2.2 of the SCM Agreement; nevertheless, it appealed this finding because it disagreed with the basis on which the Panel reached this conclusion (Appellate Body Report, 2011, US-Anti-Dumping and Countervailing Duties, para.57). However, the Appellate Body upheld the Panel's decision as well as the premise upon which the Panel's decision was founded (Appellate Body Report, 2011, US-Anti-Dumping and Countervailing Duties, para.424).

\section{What Constitute "Public Bodies" within the Meaning of Article 1.1 (a) (1) of the SCM Agreement?}

In this dispute, China argued that the major criteria for defining "public bodies" are "entities vested with government authority and that perform governmental functions". Conversely, the United States, relying on a per se rule of majority government ownership, contended that "public bodies" are "entities controlled by a government".

\section{The Ordinary Meaning of the Terms of the Treaty}

\section{Dictionary Definitions}

To decide the proper definition of "public body", the Panel argued that the dictionary definition of "public" includes: "of or pertaining to the people as a whole; belonging to, affecting, or concerning the community or nation" (Brown, 1993: Vol. I, p. 1123 \& Vol. II, p. 2404). Both parties submitted definitions of the term which are similar to this. The Appellate Body widened the scope of definitions by encompassing: "as carried out or made by or on behalf of the community as a whole", or as "authorized by or representing the community" (Stevenson, 2007: Vol. 2, p. 2394). In addition to the term "public", the Panel and the Appellate Body also addressed the definition of "body". Accordingly, the word "body" in the sense of an aggregate of individuals is defined as "an artificial person created by legal authority, for example, a corporation, an officially constituted organization, an assembly, an institution, or a society" (Stevenson, 2007: Vol. 1, p. 261). Thus, the composite term "public body" could refer to a number of different concepts, depending on the combination of the different definitional elements. The Appellate Body therefore concluded that dictionary definitions suggest a rather broad range of potential meanings of the term "public body", which encompasses a variety of entities, including both entities that are vested with or exercise governmental authority and entities belonging to the community or nation (Panel Report, 2011, US-Anti-Dumping and Countervailing Duties, para.8.59).
When facing the problem of clarifying a term in a provision, the Panel and the Appellate Body usually first rely on dictionaries to find certain definitions of the contentious term in the dispute. The most popular dictionaries usually include the Shorter Oxford English Dictionary, Webster's New World Encyclopedia, and Black's Law Dictionary; but, recently, some less well-recognized dictionaries have been used in disputes. In the dispute US - China Dispute of Publications and Audiovisual Products, in addition to these three major resources, there were many other dictionaries involved, including the American Heritage Dictionary, Oxford English Dictionary Online, New Century Chinese English Dictionary, Monash Marketing Dictionary, Random House Unabridged Dictionary, and BNET Business Dictionary (Panel Report, 2010, China-Publications and Audiovisual Products, II 261), There is no universally accepted scope of dictionaries which could be applied in every WTO dispute. This inevitably gives rise to diverse definitions of a certain term, because every Member involved will only consider the dictionaries whose definitions favour its standpoint. In the present dispute, the Panel even made a reference to some online dictionaries, such as Free Dictionary Online and Accurate and Reliable Dictionary online while defining the term "body" (Panel Report, 2011, US-Anti-Dumping and Countervailing Duties, para.8.59). The selection of unauthoritative dictionaries gave rise to the unpersuasive definition of the term, and also weakened the Panel's argument concerning what is a public body. Although the Appellate Body emphasized that the dictionary definition is not the only criterion for ascertaining the ordinary meaning of "public bodies", the proper selection of dictionaries would be conducive to identifying the most convincing textual interpretation of the term. Therefore, the dictionary method in this dispute failed to provide a reasonable criterion for settling the proper definition of "public body".

\section{The Definitions of the Corresponding French and Spanish Terms}

China suggested that the definitions of the corresponding French and Spanish terms "organisme public" and "organismo público" in Article 1.1 of the SCM Agreement support its argument concerning the ordinary meaning of the term "public body". China argued that all three terms (including the English one) are presumed to have the same meaning under Article 33 (3) of the Vienna Convention on the Law of Treaties ("Vienna Convention"). In terms of the OECD Economics Glossary, the Agreement on Agriculture, and the Appellate Body Report in Canada-Dairy, the Spanish and French terms are equated to the English term "government agency" (Panel Report, 2011, USAnti-Dumping and Countervailing Duties, para.8.8). The United States contended that the issue in the present dispute is the interpretation of the term "public body" or "organismo público" or "organisme public", and there is no discrepancy between these terms. The definitions and usages put forward by China indicated that "public body" can have the narrow meaning of "government agency" or similar entity, but the Panel found other definitions and usages showing a broader possible scope. Thus, the Panel decided not to consider this definitional analysis to give a conclusive answer to how the term "public body" should be understood. The Appellate Body further found that dictionary definitions of these words in Spanish and French would accommodate a similarly broad range of potential meanings of the term "public body".

Pursuant to Article 33.3 of the Vienna Convention, "the 
terms of the treaty are presumed to have the same meaning in each authentic text" (United Nations, 1969, Vienna Convention on the Law of Treaties, art. 33.3). The use of the phrase "be presumed to" rather than "must" or any other words implies that this situation is presumptive but not absolute. Additionally, Article 33.4 of the Vienna Convention states that "except where a particular text prevails in accordance with paragraph 1 , when a comparison of the authentic texts discloses a difference of meaning which the application of Articles 31 and 32 does not remove, the meaning which best reconciles the texts, having regard to the object and purpose of the treaty, shall be adopted" (United Nations, 1969, Vienna Convention on the Law of Treaties, art.33.4). Both provisions suggest that different versions of a certain term could possibly carry different meanings. Furthermore, using the Spanish and French translations to explain the English version may go against the general rule of interpretation concerning "context definition" provided in Article 31 of the Vienna Convention. Therefore, this criterion may also fail to constitute proper measurements of "public body".

\section{Context}

\section{1) The Conjunction “or"}

China argued that the conjunction "or" in Article 1.1 (a) (1) between the terms "government" and "public body" does not suggest that the two terms must have wholly dissimilar and unrelated meanings, but only that the terms are not identical. China cited the report of the US-Export Restraints panel's reference to the word "or" between the phrases "a government makes payments to a funding mechanism" and "entrusts or directs a private body" in subparagraph (iv) of Article 1.1 (a) (1) as meaning that the two phrases captured equivalent government actions (Panel Report, 2011, US-Anti-Dumping and Countervailing Duties, para.8.9). In contrast to China's argument, the United States claimed that the SCM Agreement expresses distinct and different meanings for the terms "government" and "public body" by using two different terms to refer to the type of entity that can provide a financial contribution.

This is a weakness in China's argument. The word "or" used in subparagraph (iv) indicates that both methods are regarded as measures of a financial contribution by the government. But, the use of "or" may not focus on the commonalities of both; rather, it emphasizes their distinctions - the former demonstrating the financial contribution accomplished by a funding mechanism, and the latter by means of private bodies under entrustment and direction. The Panel admitted that these two phrases capture equivalent government actions only in terms of their commonalities as a financial contribution; this rule could not be reasonably applied to the relation between "a government" and "a public body". The view that, the use of "or" denotes the distinctions between both but does not reject their commonalities, was also endorsed by China.

\section{2) The Adjective "any"}

The Panel believed the separation between the terms "government" and "any public body" by the disjunctive "or" suggests that they are two separate concepts rather than a single concept or nearly synonymous; in addition, the use of the word "a" before "government" at the beginning of the clause, and the use of the word "any" before "public body" further suggest that these two terms have separate meanings. In addition, the word "any" before "public body" suggests a rather broader than a narrower meaning of that term, i.e., as referring to "public bod- ies" of "any" kind. All these contextual elements together suggest a meaning of the term "public body" as something separate from and broader than "government" or "government agency". However, China's understanding of a "public body" (an entity that exercises authority vested in it by the government for the purpose of performing functions of a governmental character) indeed put some restrictions on the scope of public bodies.

\section{3) The Collective Term "Government"}

Article 1.1 (a) (1) of the SCM Agreement in determining "subsidy" provides that "there is a financial contribution by a government or any public body within the territory of a Member (referred to in this Agreement as 'government')" (SCM Agreement, 1994, art.1.1 (a) (1)). The collective term "government" is equated to the entire phrase "a government or any public body within the territory of a Member". China, argued that the terms "a government" and "any public body" are "functional equivalents" because of the collective expression "government". However, the Panel was convinced that the use of the collective expression is merely a device to simplify the drafting, to avoid having to repeat the entire phrase "a government or any public body" throughout the SCM Agreement. A similar drafting device is employed in different places, such as "specificity" of Article 2.1 of the SCM Agreement.

However, the Appellate Body did not agree with the Panel's opinion. Accordingly, the juxtaposition of the collective term "government" on the one side and "private body" on the other side in Article 1.1, as well as the joining under the collective term "government" of both a "government" in the narrow sense and "any public body" in Article 1.1 (a) (1) of the SCM Agreement, suggests certain commonalities in the meaning of the term "government" in the narrow sense and the term "public body" and a nexus between these two concepts. When Article 1.1 (a) (1) stipulates that "a government" and "any public body" are referred to in the SCM Agreement as "government", the collective term "government" is used as a superordinate, including, inter alia, "any public body" as one hyponym. Therefore, the Appellate Body disagreed with the Panel's reasoning that the use of the collective term "government" has no meaning besides facilitating the drafting of the Agreement.

\section{4) The Term "Private Body"}

In addition to the issues discussed above, the most important contextual element in Article 1.1 (a) (1) may be the term "private body" in Article 1.1 (a) (1) (iv), and its relationship with the terms "a government" and "any public body". In particular, Article 1.1 (a) (1) describes three kinds of potential providers of subsidies for the purposes of the SCM Agreement, namely "governments", "public bodies", and "private bodies" (SCM Agreement, 1994, art.1.1 (a) (1)). In the Panel's words, from the standpoint of pure logic, this is a complete list of potential actors: every entity must fall into one of these three categories. Neither party argued that SOCBs in this dispute could in any way be termed "government" as such. Therefore, the question is the basis of distinguishing between "public" and "private" bodies.

Based on the dictionary definitions of the terms "private enterprises" ("a business etc. that is privately owned and not under State control") (Stevenson, 2007: p. 2359), and "public sector" ("that part of an economy, industry etc. controlled by the State") (Stevenson, 2007: p. 2359), the Panel suggested that a "public" body is any entity that is under State control, while a "private" body is an entity not controlled by the State, and that ownership is highly relevant to the question of control. Thus, 
the Panel concluded that, if China interpreted the term "public body" narrowly, as meaning government agencies and other entities vested with and exercising governmental authority, and as presumptively excluding government-owned and/or government-controlled enterprises, it would constitute a complete reversal of the ordinary meaning of the term "private body".

\section{Object and Purpose of the SCM Agreement}

The SCM Agreement does not contain a preamble or an explicit indication of its object and purpose. In US - Carbon Steel, the Appellate Body stated, "the main object and purpose of the SCM Agreement is to increase and improve GATT disciplines relating to the use of both subsidies and countervailing measures" (Appellate Body Report, US-Carbon Steel, 2002, para.73). This statement is of minimal use for reaching a clear definition of a "public body", because it is too abstract. In Brazil-Aircraft, the Panel considered that the object and purpose of the SCM Agreement is to impose multilateral disciplines on subsidies that distort international trade (Panel Report, BrazilAircraft, 1999, para.7.26). In Canada-Aircraft, the Panel suggested that the object and purpose of the SCM Agreement could appropriately be summarized "as the establishment of multilateral disciplines 'on the premise that some forms of government intervention distort international trade, [or] have the potential to distort [international trade]"' (Panel Report, Canada-Aircraft, 1999, para.9.119). In US-Export Restraints, the Panel expressed its agreement with the Panel in BrazilAircraft and Canada-Aircraft with regard to its statements on the object and purpose of the SCM Agreement (Panel Report, US-Exports Restraints, 2001, para.8.62). In US-Softwood Lumber IV, the Appellate Body stated that the object and purpose of the SCM Agreement are "to strengthen and improve GATT disciplines relating to the use of subsidies and countervailing measures, while, recognizing at the same time, the right of Members to impose such measures under certain conditions" (Appellate Body Report, US-Softwood Lumber IV, 2004, II 571).

The United States recalled that "the object and purpose of the SCM Agreement... includes disciplining the use of subsidies and countervailing measures, while at the same time, enabling WTO Members whose domestic industries are harmed by subsidized imports to use such remedies" (Appellate Body Report, US-Softwood Lumber IV, para.95). It is believed that interpreting the term "public body" as referring to entities controlled by the government preserves the strength and effectiveness of the subsidy disciplines, and inhibits circumvention by ensuring that governments cannot escape those disciplines by using entities under their control to accomplish tasks that would potentially be subject to those disciplines if the governments themselves undertake them. In contrast, China's restrictive interpretation would render some subsidization unreachable, which would be at odds with the object and purpose of the SCM Agreement. China took issue with this reasoning and contended, first, that the Panel wrongly believed that China's definition of "public body" was limited to formal arms or organs of government and could not encompass government-owned or -controlled entities. Second, even if a government-owned or -controlled corporation was not regarded as a public body, its conduct could still be captured by the SCM Agreement under Article 1.1 (a) (1) (iv) which includes the situations that " $a$ government makes payments to a funding mechanism, or entrusts or directs a private body to carry out one or more of the type of functions illustrated in (i) to (iii)" (SCM Agreement, 1994: art.1.1 (a) (1)).

The Appellate Body also commented on the object and purpose of the SCM Agreement in many other cases, namely US-Softwood Lumber IV and US-Countervailing Duty Investigation on DRAMS. It assumed that the consideration of the object and purpose are of limited use in delimiting the scope of the term "public body" in Article 1.1 (a) (1), mainly because the question of whether an entity constitutes a public body is not tantamount to the question of whether measures taken by that entity fall within the ambit of the SCM Agreement.

The Appellate Body then found that the Panel's object and purpose analysis did not take full account of the SCM Agreement's disciplines. While the Panel was concerned with what it saw as the implications of too narrow an interpretation, too broad an interpretation of the term "public body" could equally risk upsetting the delicate balance embodied in the SCM Agreement because it could serve as a license for investigating authorities to dispense with an analysis of entrustment and direction and instead find entities with any connection to a government to be public bodies. For that reason, the Appellate Body concludes that consideration of the object and purpose of the SCM Agreement does not favour either a broad or a narrow interpretation of the term "public body".

\section{The International Law Commission's Article}

China submitted that the rules of attribution included in the International Law Commission's Articles ("ILC Article") on Responsibility of States for Internationally Wrongful Acts, in particular, Article 4, 5, and 8, reflect customary rules of international law or general principles of law(International Law Commission, 2001, Responsibility of States for Internationally Wrongful Acts, arts.4, 5 \& 8). They are "rules of international law applicable in the relations between the parties" in the sense of Article 31 (3) (c) of the Vienna Convention and relevant to the interpretation of Article 1.1 (a) (1) of the SCM Agreement.

However, both the United States and the Panel took the view that the ILC Article need not be taken into account because, inter alia, they are not "relevant" to the interpretation of Article 1.1 of the SCM Agreement (China's appellant's submission, para.147). The Appellate Body believed that the Panel misconstrued the role of the ILC Articles when it set out to analyze "whether [the ILC Articles] would override [the Panel's] analysis and conclusion based on the text of the SCM Agreement itself' (Panel Report, 2011, US-Anti-Dumping and Countervailing Duties, para.8.84). If, as the Panel stated, certain ILC Articles have been "cited as containing similar provisions to those in certain areas of the WTO Agreement" or "cited by way of contrast with the provisions of the WTO Agreement", this could suggest that these ILC Articles have been "taken into account" in the sense of Article 31 (3) (c) by panels and the Appellate Body in these cases.

The theory of the law of state responsibility was not well developed until recently. The position has now changed with the adoption of the International Law Commission's Draft Articles on Responsibility of States for Internationally Wrongful Acts ("Draft Articles") by the ILC in August 2001 (International Law Commission, 2001, Draft on the Responsibility of States for Internationally Wrongful Acts, p.43). The Draft Articles have already been cited by the International Court of Justice and have generally been well received. However, they do not necessarily apply in all cases. Particular treaty regimes, such as 
the GATT and the European Convention on Human Rights, have established their own special rules of responsibility. The Articles have remained as a draft rather than a universally accepted treaty which is more influential and has general application. Therefore, the impact of the Articles may not illustrate the definition of "public bodies" in the context of Article 1.1 of the SCM Agreement.

\section{The GATS Financial Services Annex}

The General Agreement on Trade in Services ("GATS") was also referred by China to support its argument. Paragraph 5 (c) (i) of the Annex on Financial Services to the GATS ("GATS Financial Services Annex") defines the term "public entity" as an "entity owned or controlled by a Member, that is principally engaged in carrying out governmental functions or activities for government purpose [...]". China argued that this definition reflects a similar view of the functional equivalence between "government" and "public body". The United States challenged this point of view by merely arguing that the GATS is a different agreement with an entirely different field of application, and that the term "public entity" used in it is different from the term "public body" without providing evidence to further its reasoning.

According to what have been discussed above, the object and purpose of the SCM Agreement could be summarized as: "1) to impose multilateral disciplines on subsidies that distort international trade; 2) to strengthen and improve GATT disciplines relating to the use of both subsidies and countervailing measures, while, recognizing at the same time, the right of Members to impose such measures under certain conditions". In contrast, the GATS seeks to create a more liberal, transparent, and predictable policy environment for one of the most dynamic areas of international trade (Mattoo \& Carzaniga, 2003). The essence of the GATS lies in the liberalization of international trade in services by imposing certain restrictions and rules on the service regulation measures taken by governments, while the SCM Agreement tries to regulate the use of subsidies and countervailing measures under certain conditions, which is different from breaking down service trade barriers addressed by the GATS. In terms of their differences, it is not appropriate to apply the definition of "public entities" in the GATS to "public bodies" in the SCM Agreement.

\section{Reference to Municipal Laws}

China argued that the Panel erred, first, in relying on municipal law usages to interpret the SCM Agreement, and, second, in concluding that these usages supported its finding that government control, without more, is the single criterion that defines a "public body", "organismo público", or "organisme public" (Panel Report, 2011, US-Anti-Dumping and Countervailing Duties, para.8.87). The Appellate Body had some reservations relating to the way in which the Panel had recourse to usages of the term "public body" or similar terms in the municipal law of a number of jurisdictions in this dispute, and did not address this argument further. Yet, the Appellate Body raised several questions. First, the Panel did not clearly explain why it considered that an examination of the understanding of the concept of a public body in municipal law would assist in answering the particular interpretative question with which it was confronted. Second, while the Panel referred to the defini- tion of "public bodies" or similar terms in four different jurisdictions, it is not clear whether the Panel assessed the usage of the relevant terms only in these four jurisdictions or whether the Panel surveyed other jurisdictions as well.

\section{US-Countervailing Duty Investigation on DRAMs}

China recalled that in US-Countervailing Duty Investigation on DRAMS the Appellate Body referred to the Draft Articles in the section of its report, in particular the Commentary to Article 8 of the Draft. Accordingly, this passage of the Commentary makes clear that state ownership is not sufficient to attribute the conduct of a state-owned corporate entity to a state, and by extension to a Member for the purpose of Article 1.1 of the SCM Agreement, and that instead it supported China's view of the term "public body".

In contrast, the United States argued that the question in US - Countervailing Duty Investigation on DRAMS, of whether certain private bodies were entrusted or directed by the government within the meaning of Article 1.1 (a) (1) (iv) of the SCM Agreement, such that their provision of loans and equity was attributable to the government, was different from that in the present dispute, i.e., whether certain entities constitute "public bodies" within the meaning of Article 1.1 (a) (1) of the SCM Agreement, a question which the Appellate Body did not address in US - Countervailing Duty Investigation on DRAMS (United States first written submission, para.118, second written submission, para.41). Furthermore, the United States disagreed that the Appellate Body found the Draft Articles to be relevant rules of international law, and China read provisions of the Draft Articles into the SCM Agreement as integral parts of the text, although they are not relevant to interpreting the term "public body" (United States first written submission, para. 119).

\section{Korea-Commercial Vessels}

The Panel in Korea-Commercial Vessels can be read as endorsing the position that the question of whether an entity is a public body can be answered by solely referring to government ownership or control. China argued that its reasoning was not persuasive and should not be followed.

However, the United States agreed with the conclusion of the Panel in Korea-Commercial Vessels that "an entity will constitute a 'public body' if it is controlled by the government (or other public bodies)" (Panel Report, Korea-Commercial Vessels, 2005: p. 2749). The United States stated that majority government ownership can demonstrate control, in that government ownership gives the government the ability to appoint managers and directors to overseas operations.

China's argument was that only if, in a particular case, a government-owned or -controlled firm were actually exercising governmental authority to carry out governmental functions would such an entity, in that particular instance, be a "public body". The Panel considered that such an approach would suffer from the same flaw of mixing considerations of benefit (behavior in a particular instance) with determining the nature of the entity (without regard for its behavior in a particular instance). Contrary to China's argument, under the SCM Agreement, the question of the nature of the entity (i.e., whether it is "a government or any public body") is entirely separate from the behavior of that entity in a given instance (i.e., whether 
there is a financial contribution, whether a benefit is thereby conferred, and whether there is specificity).

\section{Analysis of SOCBs in China}

A thorough discussion of whether SOCBs constitute "public bodies" requires not only an examination of how to properly define "public bodies" but also an analysis of SOCBs in China. A detailed study on the nature of China's SOCBs involves both policy and legal approaches.

\section{Policy Approach}

China is the world's largest nation and its economy has been growing at a rate of about $9 \%$ per year over the last three decades (Outlaw, 2012, "Globalization in China"). Two economies exist in China. One is dominated by foreign-owned and familyrun private companies that have produced striking growth mainly in Guangdong and the Yangtze River Delta. The two areas, which operate a free market form of capitalism, attract $70 \%$ of China's foreign investment and contribute more than 70 $\%$ of exports (Plender, 2011, "The Weakness beneath China's Rise"). Then the other economy is the slower-growth economy dominated by state-owned enterprises, which still provide some social security for its workers. This is indeed a bank-based mode (Plender, 2011, "The Weakness beneath China's Rise"). The rapid growth of China's economy may be linked to the globalization of trade, but it has yet to "globalize" its banking sector (Berger, Hasan, \& Zhou, 2008: p. 114). China's banking system has thousands of entities, including the 12 second-tier banks, the urban and rural banks, Postal Savings Bank, and credit cooperatives (Walter \& Fraser, 2010: p. 29). The banking industry is dominated by four very large state-owned commercial banks, Industrial and Commercial Bank of China ("ICBC"), Agricultural Bank of China ("ABC"), Bank of China
("BOC"), and Construction Bank of China ("CBC") - the "Big Four" - with about half of the total industry assets (See Table 1). In 2009, state-controlled commercial banks held over US \$ 11 trillion in financial assets, of which the Big Four also accounted for over 70\% (Walter \& Fraser, 2010: p. 30). Such a concentration of financial assets in the banking system is very common in lower-income economies. However, as Fraser Howie and Carl Walter address in the book Red Capitalism, "what differs in China's case is that the central government has unshakable control of the sector", and "foreign banks hold, at best, little more than $2 \%$ of total financial assets (and only $1.7 \%$ after the lending binge of 2009), as compared to nearly $37 \%$ in the international lower-income group" (Walter \& Fraser, 2010: p. 30). Yan Li and Yuming Zhuang, in a workshop on Reform and Development of Banking System in China, stated that "financial institutions in China are dominated by banks, and banks are dominated by SOCBs; therefore, financial reform could be labeled as "reform of SOCBs" (Li \& Zhuang, 2005, "The Reform of State-Owned Commercial Banks in China") (See Table 1).

\section{Reform of China's SOCBs}

Financial reform in China is actually composed of three major phases: 1) the evolution of the framework of the modern banking system from 1979 to 1993 ; 2) transition from specialized banks to commercial banks from 1994 to 1999 ; 3) comprehensive reform of SOCBs since 2000.

Today's banking system is the child of the financial crises that began China's 30 years of reform and ended each of its next two decades (Walter \& Howie, 2010: p. 31). The Cultural Revolution in 1976 destroyed the banking system of China, leaving no banks or any other financial institutions functioning. To fix this situation, banking reform was put on the agenda in 1978. The objective of bank reform was to strengthen banks financially as well as institutionally so that Chinese bankers

Table 1.

The Assets, Deposits and Loans of Financial Institutions RMB 100 Million yuan, \%.

\begin{tabular}{|c|c|c|c|c|c|c|}
\hline & \multicolumn{2}{|c|}{ Assets } & \multicolumn{2}{|c|}{ Deposits } & \multicolumn{2}{|c|}{ Loans } \\
\hline & Balance & shares & Balance & shares & Balance & shares \\
\hline Total & 316006.68 & 1 & 248988.62 & 1 & 189298.46 & 1 \\
\hline Policy Banks & 24122.48 & $7.63 \%$ & 1274.87 & $0.51 \%$ & 22228.24 & $11.74 \%$ \\
\hline SOCBs & 169320.5 & $53.58 \%$ & 144417.48 & $58.00 \%$ & 101182.24 & $53.45 \%$ \\
\hline Joint-stock Commercial Banks & 46972.2 & $14.86 \%$ & 40598.84 & $16.31 \%$ & 28859.41 & $15.25 \%$ \\
\hline City Commercial Banks & 17056.3 & $5.40 \%$ & 14145.58 & $5.68 \%$ & 9030.97 & $4.77 \%$ \\
\hline Rural Commercial Banks & 565.36 & $2.34 \%$ & 500.8 & & 309.7 & \\
\hline Urban Credit Cooperatives & 1786.76 & $0.57 \%$ & 1588.76 & $0.64 \%$ & 1014.54 & $0.54 \%$ \\
\hline Rural Credit Cooperatives & 30767.02 & $9.74 \%$ & 27340.16 & $10.98 \%$ & 19241.56 & $10.16 \%$ \\
\hline Trust Corporations & 2674.09 & $0.85 \%$ & 1750.11 & $0.70 \%$ & 1331.85 & $0.70 \%$ \\
\hline Finance Companies & 5854.1 & $1.85 \%$ & 4954.1 & $1.99 \%$ & 3097.8 & 1.64 \\
\hline Leasing Companies & 215.37 & $0.07 \%$ & 69.32 & $0.03 \%$ & 157.2 & $0.08 \%$ \\
\hline Postal Savings Institution & 10849.6 & $3.34 \%$ & 10849.6 & $4.36 \%$ & 0 & $0.00 \%$ \\
\hline Foreign Banks & 5822.9 & $1.84 \%$ & 1499 & $0.60 \%$ & 2844.2 & $1.50 \%$ \\
\hline
\end{tabular}

Source: the People's Bank of China database, 2004. 
could offer sound judgment and advice. This resulted in the "Big Four", which served mainly as policy-lending "conduits" for the government (Walter \& Howie, 2010: p. 22). The reform was continued with the separation of commercial banks from policy banks in 1994. Since then, three specialized "policy" banks-Agriculture Development Bank of China ("ADBC”), China Development Bank ("CDB"), and Export-Import Bank of China ("the Chexim") - have undertaken the policy-related business of the "Big Four"; this divorced the "Big Four" from "policy loans" dictated by government. In 1995, the Law of the People's Republic of China on Commercial Banks ("the Law of Commercial Banks") was passed, enabling the "Big Four" to become genuine commercial banks and segregating business operations of banks, securities firms and insurance companies. The reforms then entered a new phase after the Asian financial crisis of 1997-98. According to Howie and Walter, in an unsettling portrait of a fragile economic behemoth, the Communist Party "treats its banks as basic utilities that provide unlimited capital to the cherished state-owned enterprises" (Berger, Hasan \& Zhou, 2008: p. 22). The result is a banking system that is allowed to carry huge amounts of nonperforming loans and to delay the day of reckoning (Chanceller, 2011, "China's Fiscal Legerdemain"). At that time, China's big four commercial banks had nonperforming loan ("NPL") ratios of $30 \%-50 \%$, and they were believed to be insolvent (Huang, 2009: p. 1). Thus, the Chinese authorities became serious about disposing of the NPLs of the "Big Four".

Various forms of assistance were provided by the government with limited impact, given the seriousness of the problems challenging the "Big Four". For that reason, in 1999 the government established four asset management companies wholly owned by the Ministry of Finance: Xinda, Orient, Great Wall, and Huarong (Huang, 2009: p. 2). By July 2000, these asset management companies had largely completed purchasing from the "Big Four" NPLs with a total book value of RMB 1.4 trillion, but the four SOBCs still had NPLs totaling RMB 1.8 trillion. Based on this situation, some commentators claimed that China's banks have so far escaped the consequence of their reckless lending at no apparent cost to society (Chanceller, 2011, "China's Fiscal Legerdemain"). Since the Chinese government fixed a wide spread between their borrowing costs and what they charge for lending, the banks even appear highly profitable. Yet the true cost has been borne by the Chinese people, who received artificially low rates on their deposits. This is named technically "financial repression", which in China is estimated at around $4 \%$ of gross domestic product (Chanceller, 2011, "China's Fiscal Legerdemain").

In December 2001, China joined the WTO, and promised to completely open its market to foreign banks within five years. The "Big Four" were uncompetitive with foreign banks on nearly every measure, exemplified by their high nonperforming loan ratio, low profitability, profit per employee, capital adequacy and so on (See Tables 2-5).

To deal with this situation, the "Decision on Improvement of the Socialist Market Economic System", issued by the Third Plenary Session of the $16^{\text {th }}$ Central Committee of the Communist Party of China on 14 October 2003, included proposals to choose state-owned banks that meet certain conditions to reorganize as joint stock companies, accelerate their disposal of NPLs, increase their capital, and meet the conditions required for listing their shares (Li \& Zhuang, 2005, "The Reform of
Table 2.

Nonperforming Loan Ratio.

\begin{tabular}{ccc}
\hline & 2001 & 2003 \\
\hline SOCBS & $25.40 \%$ & $20.36 \%$ \\
Japanese banks in average & & $4.50 \%$ \\
French banks in average & $4.20 \%$ \\
British banks in average & $2.4 \%$ \\
American banks in average & $1.80 \%$ \\
\hline
\end{tabular}

Source: Source: database from People's Bank of China-A fragile banking system.

Table 3.

Profit on Asset (\%).

\begin{tabular}{ccccc}
\hline & 1999 & 2000 & 2001 & 2002 \\
\hline SOCBs & $0.11 \%$ & $0.13 \%$ & $0.12 \%$ & $0.24 \%$ \\
ICBC & & & $0.14 \%$ & $0.13 \%$ \\
ABC & & & $-0.24 \%$ & $-0.03 \%$ \\
BOC & & & $0.35 \%$ & $0.45 \%$ \\
CBC & & & $0.21 \%$ & $0.50 \%$ \\
Joint-stock banks & $0.36 \%$ & $0.39 \%$ & $0.30 \%$ & - \\
Foreign banks in China & $2.67 \%$ & $1.92 \%$ & $2.26 \%$ & - \\
\hline
\end{tabular}

Source: China Financial Yearbook, 1999-2003.

Table 4.

Profit per Employee (thousand dollars).

\begin{tabular}{cc}
\hline & 2003 \\
\hline SOCBs (excludes ABC) & 2.5 \\
Top 10 banks in the world & 152 \\
\hline
\end{tabular}

Source: Yan Li and Yumin Zhuang, ASEAN + 3 Workshop on Reform and Development of Banking System in China, May 24-26, 2005, Shanghai, China.

Table 5.

The Capital Adequacy Ratio of SOCBs.

\begin{tabular}{cccc}
\hline & 1997 & 1999 & 2002 \\
\hline ICBC & $2.55 \%$ & $5.70 \%$ & $5.54 \%$ \\
ABC & $2.14 \%$ & $5.10 \%$ & $1.44 \%$ \\
BOC & $4.70 \%$ & $3.00 \%$ & $8.15 \%$ \\
CBC & $2.73 \%$ & $2.50 \%$ & $6.91 \%$ \\
\hline
\end{tabular}

Source: Annual Reports of the Big Four (1997, 1999, 2002). Capital adequacy ratio had been reached $8 \%$ after the Ministry of Finance injected $\$ 33$ billion in SOCBs in 1998. But the ratio kept declining after that.

State-Owned Commercial Banks in China") (See Table 6).

On 31 December 2003, the State Council invested a total of $\$ 45$ billion of foreign currency reserves equally in BOC and $\mathrm{CBC}$. The two banks were chosen first because BOC had the highest capital ratio of the "Big Four", and $\mathrm{CBC}$ had the lowest NPL ratio. The entities that exercised their rights as major shareholders in BOC and $\mathrm{CBC}$ and received profits and dividends from their investment were the Ministry of Finance and 
Table 6.

Substantial Improvement in the Financial Indicators of State-Owned Banks that Reorganized as Joint-Stock Companies (\% and RMB billions).

\begin{tabular}{|c|c|c|c|c|c|}
\hline & & 2005 & 2006 & 2007 & 2008 \\
\hline & Capital ratio & 9.89 & 14.05 & 13.09 & 13.06 \\
\hline \multirow[t]{3}{*}{ Industrial \& Commercial Bank of China } & NPL ratio & 4.69 & 3.79 & 2.74 & 2.29 \\
\hline & Retax profits & 59.35 & 71.52 & 115.11 & 145.30 \\
\hline & Capital ratio & 10.42 & 13.59 & 13.34 & 13.43 \\
\hline \multirow[t]{3}{*}{ Bank of China } & NPL ratio & 5.41 & 4.04 & 3.12 & 2.65 \\
\hline & Retax profits & 55.14 & 67.63 & 89.96 & 86.25 \\
\hline & Capital ratio & 13.57 & 12.11 & 12.58 & 12.16 \\
\hline \multirow[t]{3}{*}{ China Construction Bank } & NPL ratio & 3.84 & 3.29 & 2.60 & 2.21 \\
\hline & Retax profits & 55.36 & 65.72 & 100.82 & 119.74 \\
\hline & Capital ratio & 11.20 & 10.83 & 14.44 & 13.47 \\
\hline \multirow[t]{2}{*}{ Bank of Communication } & NPL ratio & 2.37 & 2.01 & 2.05 & 1.92 \\
\hline & Retax profits & 12.84 & 17.41 & 31.04 & 35.82 \\
\hline
\end{tabular}

Source: People's Bank of China, (China Financial Stability Report), 2009 (in Chinese).

Central Huijin Investment Company Ltd. (“Central Huijin”), which were jointly capitalized by the PBOC and the State Administration of Foreign Exchange ("SAFE"). Central Huijin used foreign exchange reserves to invest $\$ 15$ billion in ICBC in April 2005, \$20 billion in the China Development Bank to convert it from a policy bank to a commercial bank in December 2007, and $\$ 19$ billion in the ABC in November 2008 .

With the goal of NPL dispositions having been met, the "Big Four" had gradually achieved the conversion of state-owned banks to joint stock companies, with the Ministry of Finance and Central Huijin as major shareholders. Before 2006, China had only four SOCBs. The Bank of Communications ("BoComm") as the fifth largest state-controlled joint-stock commercial bank then joined the "SOCBs" group in 2006, and China now has five SOCBs (Wen, 2010, "Ownership Structure and Bank Performance in China"). Meanwhile, the China Bohai Bank was added to the joint-stock commercial banks ("JSCBs") group in the same year. The current relation between SOCBs and JSCBs can be demonstrated by Figure 1 (Wen, 2010, "Ownership Structure and Bank Performance in China"). After this period, the focus of reforms aimed at the public listing of SOCBs has shifted to attracting strategic investors from overseas, because it could not only enhance capital but also improve both managerial and governance capabilities. For those foreign financial institutions, investment in one of the "Big Four" was a way to enter the Chinese market.

In August 2004, the Hong Kong and Shanghai Banking Corp. ("HSBC") became BOC's first strategic investor from overseas. By acquiring $19.9 \%$ of its shares, HSBC became the foreign financial institution with the largest stake in China's banking sector. Then in 2005, the Bank of America acquired a 9.0\% stake, and Temasek a 5.1\% stake, in CBC, and Royal Bank of Scotland, UBS, Asian Development Bank, and Temasek took a combined $16.19 \%$ stake in BOC (Li \& Zhuang, 2005, "The Reform of State-Owned Commercial Banks in China", p. 4). In 2006, Goldman Sachs, Allianz, and American Express together invested $\$ 3.8$ billion to purchase an $8.4 \%$ stake in ICBC.

Despite bold reforms taking place in the late 1990s and early 2000s, the financial reform process, from about 2005, slowed and then came to a halt. According to Walter, the author of Red Capitalism, this is due to the fact that the main political figures supporting reform, Prime Minister Zhu Rongji and President Jiang Zhemin, had been replaced, and the key vice premier in charge of finance came down with cancer in 2005. This seriously weakened those implementing the financial reform measures that had begun in earnest in 1997 (Barboza, 2013, "A Conversation with Carl Walter"). At the same time, three of the "Big Four" had completed unexpectedly successful IPOs by 2006, so it may have seemed to the new government that the principal reform objectives had been achieved (Barboza, 2013, "A Conversation with Carl Walter"). Walter and Howie have established through their analysis that China is unlikely now to construct an economy or state which mirrors the "classical" or "normal" style of capitalism in the West (Taaffe, 2011, "Book Review: Halfway House-'Red Capitalism"'). Although the state-owned system has many forms of western financial modes such as stock exchanges, bond markets, interbank markets and so forth, they regard this as "camouflage" (Plender, 2011, "The Weakness beneath China's Rise"). On the exchanges, initial public offerings merely redistribute capital among state entities with occasional leakage to retail investors (Plender, 2011, "The Weakness beneath China's Rise"). The government bond market mainly shuffles paper between different arms of state enterprise at officially administered interest rates no different from those charged by banks (Plender, 2011, "The Weakness beneath China's Rise"). In this regard, Walter and Howie believe that capital allocation is controlled by the Communist party. As they state in the preface of their book: "It is a simple fact that China's financial system and its stock, bond and loan markets cater only to the state sector, of which the 'National Champions' represent the reddest of the Red. These corporations, the heart of China's state-owned economy, are 'inside the system'. The private economy, no matter how vibrant, is 'outside the system' and, in fact, serves the will of the system" (Taaffe, 2011, "Book Review: Halfway House-'Red Capitalism'”'). It has been contentious that China has not and may not complete a full transi- 


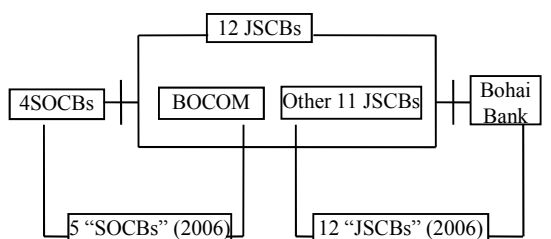

Figure 1.

The Current Relation between SOCBs and JSCBs.

tion to capitalism as we know it in other areas of the world (Taaffe, 2011, "Book Review: Halfway House-'Red Capitalism"").

\section{The Entry of Strategic Investors}

In the process of reforming the "Big Four", the Chinese government and foreign investors seemed to agree that engaging the expertise of international strategic partners has the potential to improve virtually every dimension of Chinese banks' performance-overall governance; control and management of operations; introduction and marketing of new products; enhancement of asset quality; comprehensive, timely and accurate compilation of management information; better management of risk; stronger capital positions and better returns on equity; and rehabilitation of the banks' reputations (Hope \& Hu, 2006: p. 35). In addition, international strategic investors' investment could confirm to the international investor community that the banks had been successfully restructured and now represented an attractive investment opportunity (Walter \& Howie, 2010: p. 22). In short, the introduction of foreign strategic investment holds tremendous promise for the reform of the Chinese banking system, and both international investors and Chinese banks can potentially forge a mutually beneficial partnership.

However, problems still exist in the partnership, exemplified by foreign investors' inability to gain meaningful control and influence over the Chinese banks. This fact was used by the United States in the present dispute to support the claim that the Chinese government virtually has the effective and absolute control of the "Big Four". This may be the major reason that the Panel believed that China's SOCBs constitute "public bodies" within the meaning of Article 1.1 (a) (1) the SCM Agreement. Despite the entry of strategic investors, majority ownership still lies in the hand of the Chinese government (See Table 7).

Although China's socialist market economy includes many private entities and a wide variety of economic sectors, it is mainly based on public ownership by upholding and improving various forms of public ownership entities. This mixed-ownership structure with public ownership as the mainstay, particularly in the large and medium-sized key state-owned and state holding enterprises, could exploit its advantages to the full by guaranteeing the rational distribution and reservation of national resources as well as orderly market operation. China's SOCBs have served as the crucial pillar in the whole financial system, and their development is closely related to the progress of the national economy and society. Therefore, some Chinese scholars argue that domestic majority ownership of the "Big Four" is necessary in the process of joint-stock transformation (Song \& Liang, 2006: pp. 43-46). Although the reform has realized the diversity of the ownership, the majority shareholders of SOCBs still represent the Chinese government. Others add
Table 7.

Banks' Shareholder Composition after the Entrance of Strategic Investors.

\begin{tabular}{|c|c|c|}
\hline Commercial Banks & Strategic Investors & Equity Stake \\
\hline \multirow{5}{*}{$\begin{array}{c}\text { Bank of } \\
\text { Communications }\end{array}$} & Ministry of Finance & 25.53 \\
\hline & HSBC (UK) & 19.90 \\
\hline & $\begin{array}{c}\text { National Council for Social } \\
\text { Security Fund }\end{array}$ & 14.22 \\
\hline & Central Huijin Investment & 7.68 \\
\hline & Others & 32.67 \\
\hline \multirow{8}{*}{$\begin{array}{c}\text { China Construction } \\
\text { Bank }\end{array}$} & Central Huijin Investment & 71.13 \\
\hline & China Construction Bank & 10.65 \\
\hline & Bank of America (US) & 9.00 \\
\hline & Temasek (Singapore) & 5.10 \\
\hline & Shanghai Baosteel & 1.55 \\
\hline & State Grid Corp. of China & 1.55 \\
\hline & China Yangtze Power & 1.03 \\
\hline & Central Huijin Ivestment & 79.90 \\
\hline \multirow{5}{*}{ Bank of China } & RBS (UK) & 9.61 \\
\hline & Temasek (Singapore) & 4.80 \\
\hline & $\begin{array}{l}\text { National Council for Social } \\
\text { Security Fund }\end{array}$ & 3.91 \\
\hline & USB (Switzerland) & 1.55 \\
\hline & Asian Development Bank & 0.23 \\
\hline \multirow{6}{*}{$\begin{array}{c}\text { Industrial \& } \\
\text { Commercial Bank of } \\
\text { China }\end{array}$} & Ministry of Finance & 43.28 \\
\hline & Central Huijin Investment & 43.28 \\
\hline & Goldman Sache (US) & 5.75 \\
\hline & $\begin{array}{c}\text { National Council for Social } \\
\text { Security Fund }\end{array}$ & 5.00 \\
\hline & Alianz (Germany) & 2.25 \\
\hline & American Express (US) & 0.45 \\
\hline
\end{tabular}

Source: Nomura Institute of Capital Markets Research, based on each bank's annual report and prospectus.

that the control of the "Big Four" by the government is inevitable, but this control should be properly restricted; the key strategy is to introduce foreign strategic investors to effectively and reasonably limit the state majority shareholders (Song \& Liang, 2006: pp. 43-46). With the entry of those strategic investors, the ownership and control of SOCBs by the government have been moderated, which could help prevent inappropriate governmental intervention (Duan, 2003: pp. 59-66). The entry of strategic investors into China's banking sector, in particular the "Big Four", has been slow but steady during the past decade. Less state ownership and control could not be realized overnight.

\section{The Function of China's SOCBs}

In China's banking system (See Figure 2), different banks perform different functions. The PBOC is China's central bank, which formulates and implements monetary policy; it also maintains the banking sector's payment, clearing and settlement 


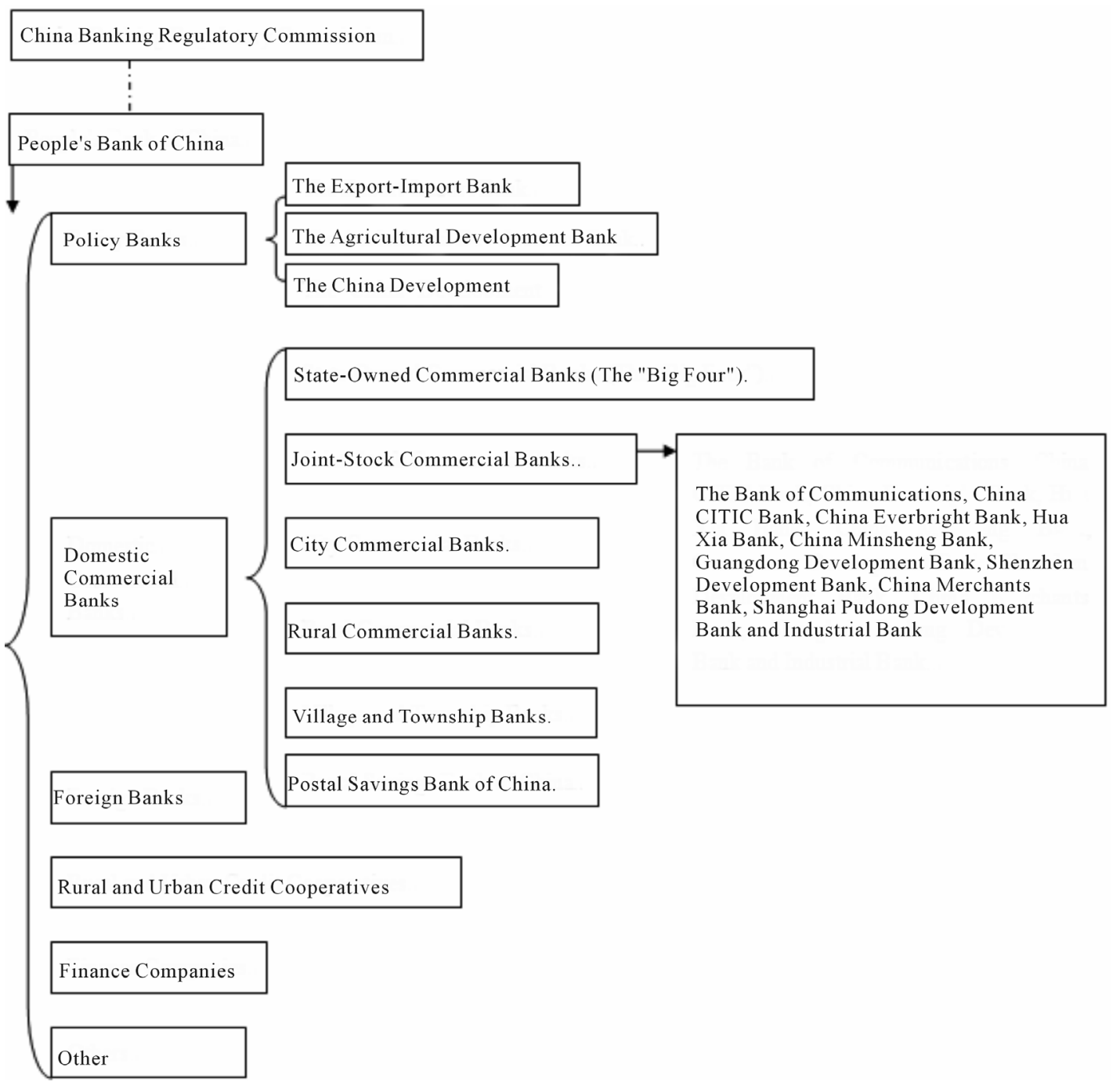

Figure 2.

The Financial Banking System in China.

systems, and manages official foreign exchange and gold reserves.

The three policy banks in China, $\mathrm{ADBC}, \mathrm{CDB}$, and the Chexim, were established in 1994 to take over the governmentdirected spending functions of the four state-owned commercial banks (Usa, 2008: p. 229). These banks are responsible for financing economic and trade development and state-invested projects as well as promoting mechanical and electrical products. ADBC provides funds for agricultural development projects in rural areas; $\mathrm{CDB}$ specializes in infrastructure financing, and the Chexim specializes in trade financing (Usa, 2009: p. 179).

The establishment and development of policy banks are the outcomes of state intervention and economic regulation. In the process of China's economic growth, some fields have failed to attract investment from profit-oriented commercial banks; those fields share the commonalities of being long-term, least-profitable, capital-demanding, and large-scale, with the development of the national economy as a top priority. To support these projects, the governments of different countries have undertaken a variety of measures, in particular the establishment of policy banks with the main purpose of financing those projects. For example, the mission of $\mathrm{CDB}$ is to "provide medium-to long-term financing facilities that assist in the development of a robust economy and a healthy, prosperous community" (China Development Bank, "Mission Statement", n.d.). It aligns its business focus with national economic strategy and allocates resources to break down bottlenecks in China's economic and social development.

Compared to the three policy banks whose capital is mainly appropriated from governmental finance, the four SOCBs have some unique features. They are in fact not organs of the government or charitable institutions but "enterprises with the main purpose of profit-making ('To Strength the Public-Service Functions of SOCBs,' n.d.)", while policy banks aim to obtain social and economic benefits on behalf of the state and people. For instance, according to the official websites, the businesses of ICBC include various aspects (See Figure 3), whereas the homepage of CDB includes several categories: business overview, investor service, special loan, and social responsibility. This makes clear that policy banks are policy-oriented, whereas SOCBs are profit-motivated. Furthermore, in contrast to stateoriented policy banks, the four SOCBs are customer-oriented. For example, ICBC undertakes business re-orientation by better 


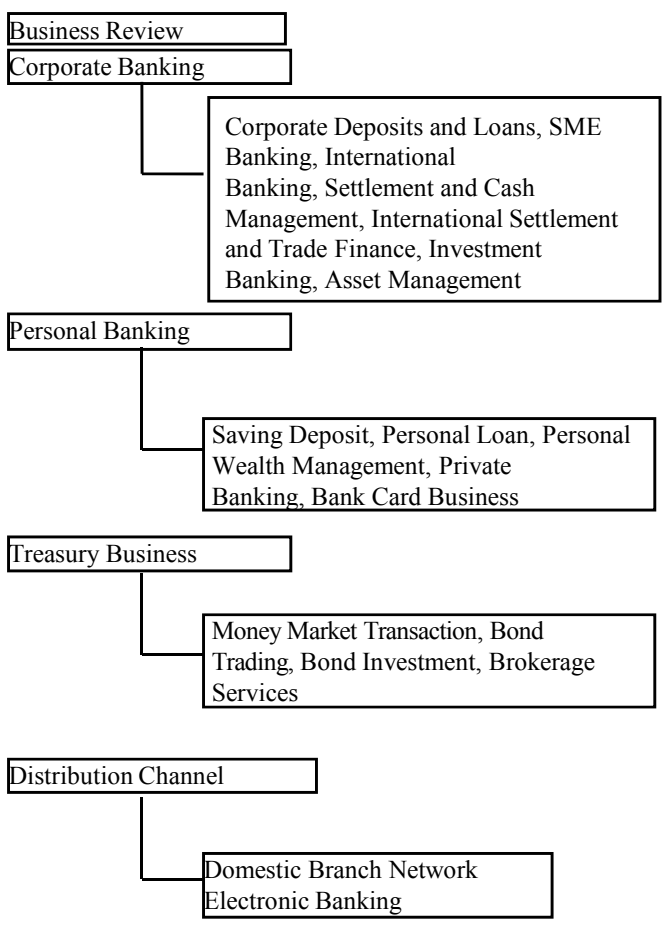

Year of Process Restructuring, Service Improvement

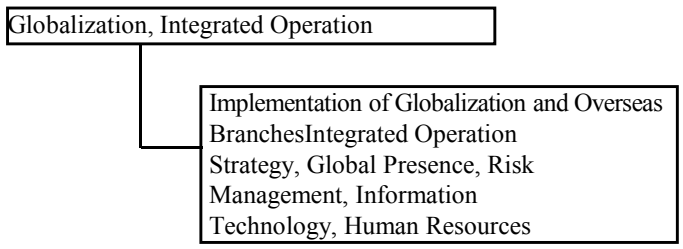

\begin{tabular}{l}
\hline IT and Product Innovation \\
\hline $\begin{array}{l}\text { Systems and Applications } \\
\text { Continuous Innovation on Products and } \\
\text { Services } \\
\text { Continuous Improvement in IT Management } \\
\text { and Innovation Management }\end{array}$ \\
Human Resource Management \\
Social Responsibility
\end{tabular}

Figure 3.

The Businesses of ICBC.

aligning itself with the diversified needs of financial services by its customers ("ICBC Business Review", n.d.).

Some scholars argue that, in the case of the four SOCBs, being "profit-oriented" does not conflict with "perform governmental functions". However, banks or financial institutions in different countries have to adhere to state financial policies and cooperate in meeting the macro-economic goals of their countries; the only difference lies in the form. This suggests that commercial banks perform some governmental functions in their countries. In the case of the "Big Four", they inevitably perform some governmental functions in accordance with state policy and purpose, but their policy nature has been largely marginalized since the establishment of policy banks. Currently, the governmental function of the "Big Four" is subsidi- ary and short-term.

\section{Sub-Conclusion}

As discussed in the policy approach, the majority ownership of SOCBs has remained in the hands of the Chinese government, although they have gone through several stages of reforms and have been joined by various foreign strategic investors. However, the policy-oriented nature of SOCBs has been largely marginalized since the establishment of policy banks. Therefore, the "Big Four", like commercial banks in other countries, only perform their subsidiary governmental functions in line with state policy and macro-economic goals. In essence, they are currently profit-motivated enterprises.

\section{Legal Approach}

As mentioned in the third section of this paper, the USDOC determined that SOCBs in the investigation constituted "public bodies" based on several reasons: 1) "near complete stateownership of the banking sector in China"; 2) Article 34 of the Commercial Banking Law, which states that banks are required to "carry out their loan business upon the needs of [the] national economy and the social development and under the guidance of State industrial policies"; 3) record evidence indicating that SOCBs still lack adequate risk management and analytical skills; and 4) the fact that "during [that] investigation the $[U S D O C]$ did not receive the evidence necessary to document in a comprehensive manner the process by which loans were requested, granted and evaluated to the paper industry" (Panel Exhibit CHI-93, pp. 58-60).

\section{Majority Ownership}

In the present dispute, the United States, relying on a per se rule of majority government ownership, argued that "entities controlled by a government" constitute "public bodies". The USDOC's determination that SOCBs in the investigation constituted pubic bodies relies on "near complete state-ownership of the banking sector in China". Based on the reasoning of the United States, several questions are raised: 1) what is the proper definition of "control"; 2) does "majority ownership" coincide with "state control"; 3) is it appropriate to use "near complete state-ownership" in the case of China's SOCBs?

The Panel agreed with the United States' argument that a public body is any entity that is under state control, and that ownership is highly relevant to the question of control. However, neither gave a specific definition of the term "control" or any indicia other than state ownership. Does the state or government decide all the aspects of SOCBs, including governance structure, daily business and management, and shareholder structure?

In addition to the term "control", the extent of state ownership is emerging as an important area to define. As V.V. Ramanadham states in the book Privatization: A Global Perspective, majority ownership may not exactly coincide with "publicness" or state control (Ramanadham, 1993: p. 23). He explains that some minority ownerships may permit tight government control; or even enterprises without state ownership but with intense dependence on the state for resources-for example, funds, market rights, sales to the public sector and other forms of dependence - may be subject to tighter controls than enterprises with state ownership (Ramanadham, 1993: p. 23). Also, "publicness", according to Ramanadham, defined as 
state control is a continuum on which most or all of enterprises of the economy can be placed (Ramanadham, 1993: p. 23). Most governments used to exercise control through their ownership of shares: they have become the most powerful shareholders across much of the developing world. But increasingly they prefer to dilute their shareholdings. Some governments have mastered "the art of controlling companies through minority stakes": in Russia, for example, the state has retained golden shares in 181 firms ("New Masters of the Universe", 2012: p. 6).

Third, in the report, the USDOC used "near complete stateownership of the banking sector in China" to support the position that SOCBs are "public bodies". However, the phrase "near complete" is ambiguous. The 2012 Annual Report of ICBC shows that state-owned shareholders, Central Huijin and Ministry of Finance, together account for $70.8 \%$ of the total shareholding ("2012 Annual Report of Industrial \& Commercial Bank of China", p. 96). This percentage is far from being "near complete".

Law of the People's Republic of China on Commercial Banks

In 1995, the Law of Commercial Banks was promulgated, legally establishing the status of the "Big Four" as SOCBs, which indicated that the "Big Four" began to change to commercial banks.

The USDOC argued in the dispute that SOCBs constitute "public bodies" by referring to Article 34 of the Law of Commercial Banks which states that "commercial banks shall carry out their loan business upon the needs of national economy and the social development and under the guidance of the state industrial policies" (the Law of Commercial Banks, art.34). The USDOC's determination depended on a single article, which may not be adequate and persuasive; indeed, there are some other prominent articles in the Law of Commercial Banks which may lead to the opposite conclusion.

Article 2 of the Law refers "commercial banks" to be "those enterprises legal persons which are established to absorb public deposits, make loans, arrange settlement of accounts and engage in other businesses in accordance with this law and the Company Law of the People's Republic of China ('the Company Law')" (the Law of Commercial Banks, art.2). There are two aspects of this article that should be emphasized: 1) the term "enterprises legal persons"; 2) commercial banks are regulated under the Law of Commercial Banks along with the Company Law. Both facts suggest that commercial banks are in essence independent enterprises or companies rather than "public bodies".

Article 4 provides that "commercial banks shall work under the principle of safety, fluidity and efficiency, with full autonomy and assume sole responsibility for their own risks, profits and losses, and with self-restraint" (the Law of Commercial Banks, art.4). This is one of the core articles of the Law of Commercial Banks, since it sets out the key principles for SOCBs to follow. Safety, fluidity, and efficiency suggest that SOCBs are enterprises which prioritize their economic benefits and efficiency ahead of state policies. Also, the phrase "under the guidance of" implies that the "state industrial policies" only play a guiding role rather than have a decisive effect on commercial banks' loan business. The meaning of Article 34 should be properly interpreted in the context. Although "commercial banks shall carry out their loan business... under the guidance of the state industrial policies", they shall "still strictly check the use of loan by the borrower, the repayment ability of the borrower, and modes of repayment" (the Law of Commercial Banks, art.35). Furthermore, when granting loans, a commercial bank shall "separate the checking process with the actual lending, and make examination and approval level-by-level" (the Law of Commercial Banks, art.35). In order to be granted loans, the borrower is required to provide a guarantee; a commercial bank shall closely check the ability of the guarantor, the ownership and value of the guaranty, pledge, and the feasibility for realizing the right to mortgage or pledge (the Law of Commercial Banks, art.36). SOCBs' loan business is not policy-oriented; rather, they take the ability of borrowers and guarantees into serious consideration before they decide to lend loans. They have their own evaluation system and criteria, "provisions on the management of the asset-liability ratio (the Law of Commercial Banks, art.38)", instead of being bound by "state industrial policies".

Furthermore, the most persuasive evidence may be Article 41 which states that "no entity or individual may coerce a commercial bank into granting loans or providing a guarantee. A commercial bank shall have the right to refuse any entity or individual to force it to do so" (the Law of Commercial Banks, art.41). Although there is no further explanation of whether "entity" includes the state or government, it should be interpreted to have this meaning included; "entity or individual" should be an exhaustive classification. This suggests that commercial banks' loan decisions are actually independent of state policies, even if they act in accordance with the state's macroeconomic goals.

\section{Corporate Governance}

During 2004 and 2005, BOC, CBC, and ICBC were transformed into shareholding limited liabilities companies. Modern corporate governance practices were introduced (Tam, "Emerging Best Governance Practices"). Corporate governance is "not only a legal discipline which is situated at the heart of company law but also a very important concept which is related to the economic life of banks and other financial institutions" ("The Corporate Governance Reform of State-owned Commercial Bank in China", p. 34).

Although there is no generally accepted definition of corporate governance, Stijn Claessens suggests that definitions in this regard can be divided into two categories. The first set of definitions concerns a set of behavioural patterns namely the actual behaviour of corporations comprising performance, efficiency, growth, financial structure, and treatment of shareholders and other stakeholders (Claessens, 2002). The second set of definitions focuses on the rule under which companies operate within the legal system, the judicial system, financial markets and labour markets (Claessens, 2002). This section will analyze the corporate governance of SOCBs in terms of the first set of definitions. From a banking industry perspective, a corporate governance system can be defined as "a set of mechanisms in setting the incentives for a banking organization to act prudently and for control of the risks that a bank takes" (Zhou \& Li, 2002: p. 215)

Indeed, corporate governance refers to the relationship that exists between the different participants. The main actors included in corporate governance are: 1) the CEO, i.e., the management; 2) the board of directors; 3) the shareholders (Prasad, 2006: p. 1). According to the Company Law, manager, directors, and shareholders assume different responsibilities and play different roles in daily business (See Table 8). 
Table 8.

Functions and Powers of Shareholders, Directors, and Managers.

\begin{tabular}{|c|c|c|}
\hline Shareholders & Directors & Managers \\
\hline $\begin{array}{l}\text { 1. decide on the business policy and } \\
\text { investment plans }\end{array}$ & $\begin{array}{l}\text { 1. be responsible for convening shareholders' meeting } \\
\text { and report its work to shareholders' meeting }\end{array}$ & $\begin{array}{l}\text { 1. be in charge of the management of the } \\
\text { production and business operations of the company } \\
\text { and organize the implementation of the resolutions } \\
\text { of the board of directors }\end{array}$ \\
\hline $\begin{array}{l}\text { 2. elect and replace any director or } \\
\text { supervisor }\end{array}$ & $\begin{array}{l}\text { 2. implement the resolutions of } \\
\text { the shareholders' meeting }\end{array}$ & $\begin{array}{l}\text { 2. organize the implementation of the company's } \\
\text { annual business plans and investment plans }\end{array}$ \\
\hline $\begin{array}{l}\text { 3. consider and approve reports of the } \\
\text { board of directors }\end{array}$ & 3.decide on the business plans and investment plans & $\begin{array}{l}\text { 3.draft the plan for establishment of the company's } \\
\text { internal management organization }\end{array}$ \\
\hline $\begin{array}{l}\text { 4. consider and approve reports of the } \\
\text { board of supervisors or the supervisors }\end{array}$ & $\begin{array}{l}\text { 4. formulate the proposed annual financial budgets } \\
\text { and final accounts }\end{array}$ & 4. draft the company's basic management system \\
\hline $\begin{array}{l}\text { 5. consdier and approve the proposal } \\
\text { annual financial budgets and final account }\end{array}$ & $\begin{array}{l}\text { 5. formulate the profit distribution plans and plans for } \\
\text { making up losses }\end{array}$ & $\begin{array}{l}\text { 5. formulate the specific rules and regulations of } \\
\text { the company }\end{array}$ \\
\hline $\begin{array}{l}\text { 6. consider and approve the profit } \\
\text { distribution plans and plans } \\
\text { for making up losses }\end{array}$ & $\begin{array}{l}\text { 6. formulate plans for the increase or reduction of the } \\
\text { registered capital and for issue of bonds } \\
\text { by the company }\end{array}$ & $\begin{array}{l}\text { 6. propose the appointment or dismissal of the } \\
\text { deputy manager (s) and chief financial } \\
\text { officer of the company }\end{array}$ \\
\hline $\begin{array}{l}\text { 7. pass resolutions on the increase or } \\
\text { reduction of the registered capital }\end{array}$ & $\begin{array}{l}\text { 7. draft plans for the merger, split, restructuring or } \\
\text { dissolution of the company }\end{array}$ & $\begin{array}{l}\text { 7. decide on the appointment or dismissal of } \\
\text { management personnel other than those } \\
\text { appointed or dismissed by the board of directors }\end{array}$ \\
\hline $\begin{array}{l}\text { 8. pass resolutions on the issue of bonds } \\
\text { by the company }\end{array}$ & & $\begin{array}{l}\text { 8. other functions and powers as granted by the } \\
\text { board of directors }\end{array}$ \\
\hline \multicolumn{3}{|l|}{$\begin{array}{l}\text { 9. pass resolutions on matters such as the } \\
\text { merger, split, restructuring, } \\
\text { dissolution or liquidation }\end{array}$} \\
\hline \multicolumn{3}{|l|}{ 10. amend the articles of association } \\
\hline $\begin{array}{l}\text { 11. other functions and powers as provided } \\
\text { for in the article of association } \\
\text { of the company }\end{array}$ & & \\
\hline
\end{tabular}

Source: The Company Law of the People's Republic of China (Article 38, 47, and 50).

Article 4 of the Company Law states that "shareholders of a company shall enjoy rights and interest according to law, such as gaining benefits from its assets, making major decisions and selecting managerial personnel" (the Company Law, 2005, art.4). This indicates that shareholders do not personally engage in operating the daily business of SOCBs; rather, the manager shall be "in charge of the management of the production and business operations of the company and organize the implementation of the resolutions of the board of directors" (the Company Law, 2005, art.50 (1)). Although a manager is appointed by and shall be accountable to the board of directors (the Company Law, 2005, art.50) who shall be accountable to the shareholders (the Company Law, 2005, art.47), the influence of a shareholder on daily business decisions or on operations may be indirect and weak. However, the fact is that currently the majority state shareholders are very influential, because the current system of appointing and dismissing directors in SOCBs is not in line with the Company Law.

First, accordingly, directors shall be elected and replaced by shareholders according to the Company Law (the Company Law, 2005, arts.38 \& 39), while Article 17 of the Supervision and Administration of State-owned Assets of Enterprises Tentative Regulations ("SASAETR") (Supervision and Administration of State-owned Assets of Enterprises Tentative Regulations, 2003, art.17) provides:

State-owned assets supervision and administration authorities shall appoint and dismiss or propose the appointment and dismissal of the responsible persons of enterprises in accor- dance with relevant regulations: ...

3. Nominate candidates for the positions of director and supervisor of State-controlled companies, recommend candidates for the positions of chairman of the board of directors, vice chairman of the board of directors and chairman of the board of supervisors of State-controlled companies, and propose candidates for the positions of general manager, deputy general manager and chief accountant of such companies in accordance with the articles of association of the companies; and

4. Nominate candidates for the positions of directors and supervisors of companies in which the State has an equity participation in accordance with the articles of association of the companies...

Accordingly to a survey, among all SOCBs, there were 42 directors, 3 appointed by the Ministry of Finance, 16 by Central Huijin, 11 by big commercial banks, 10 independent directors, 1 from another (Li, 2009: p. 62). About $42.9 \%$ of directors were designated by China's administrative organs. Since the state shareholders hold majority ownership of SOCBs, they have an overwhelming advantage over other shareholders in selecting specific directors. As a result, other shareholders' rights to select directors are implicitly denied.

Second, the Company Law provides that directors are selected by shareholders, and are motivated by various incentive mechanisms; their personal benefits are closed associated with the existence and progress of companies. Under the circumstance, directors often develop a sense of identity with their companies. However, Article 22 of the SASAETR states: 
When the shareholders' meetings or board meetings of Statecontrolled companies and companies in which the State has an equity participation decide on major matters such as division, merger, bankruptcy, dissolution, increase or decrease in capital, issue of corporate bonds, appointment or dismissal of responsible persons of enterprises, etc., the shareholders' representative and director appointed by the State-owned assets supervision and administration authority shall express opinions and exercise his voting rights as directed by the State-owned assets supervision and administration authority.

Furthermore, Article 18 and 19 of the SASAETR state (Supervision and Administration of State-owned Assets of Enterprises Tentative Regulations, 2003, arts.18 \& 19):

Article 18 State-owned assets supervision and administration authorities shall establish systems for assessment of the management performance of responsible persons of enterprises, sign a performance contract with the responsible persons of enterprises that they appoint, and conduct annual and office term assessment of the responsible persons in accordance with the performance contract.

Article 19 State-owned assets supervision and administration authorities shall, in accordance with relevant regulations, determine the remuneration of the responsible persons of wholly State-owned enterprises and companies among the Funded Enterprises, and shall decide on the rewards and penalties for the responsible persons that they appointed to the Funded Enterprises based on the results of the assessments.

Faced with the different requirements of the SASAETR and Company Law, on one hand, directors have to consider the benefits of all the shareholders and SOCBs, and on the other hand, they should assume the "administrative responsibility" of following the "order" of the majority state shareholders in order to ensure the appreciation of state-owned assets. Yet, in competition in the banking sector, the two aspects usually have different orientations and pose a dilemma with which directors must make an either-or decision.

\section{Sub-Conclusion}

Although the United States advocated that entities controlled by a government are public bodies by relying on the majority ownership criterion, they failed to demonstrate that a state majority ownership is the single and most convincing evidence of "control". SOCBs, according to the Law of Commercial Banks, are enterprises which prioritize their economic benefits and efficiency. From the theory of corporate governance, the influence of the state majority shareholders is indirect in terms of business and operation of SOCBs; but, they still have an overwhelming advantage over other shareholders in selecting directors. As a result, the selected directors face a dilemma between pursuing the benefits of all the shareholders and following the orders of the majority state shareholders.

\section{Existence of Subsidies}

The discussion of whether SOCBs constitute "public bodies" within Article 1.1 (a) (1) could not arrive at a conclusion by merely analyzing the definition of "public bodies" and the nature of SOCBs. A thorough study should also include the issue of whether subsidies exist in the present dispute. If China's SOCBs constitute private bodies, there will be two situations: 1) these private bodies themselves directly provide loans to the tire industry; 2) these private bodies are entrusted or directed by the government to provide a financial contribution listed in sub-paragraph (i) to (iii) of Article 1.1 (a) (1). In the first case, there will be no need for further discussion; because private bodies lending loans without instructions or entrustment from the government to the tire industry are not subject to the SCM Agreement; but, the second case needs detailed analysis. However, if China's SOCBs constitute public bodies, as concluded above, it will be necessary to further discuss whether subsidies exist. Article 1.2 of the SCM Agreement establishes that subsidies in the sense of Article 1 are subject to the SCM Agreement only if they are specific in the sense of Article 2 (Panel Report, US-Anti-Dumping and Countervailing Duties, para.9.29).

Article 1.1 provides that a subsidy exists where "there is a financial contribution by a government or any public body within the territory of a Member" or "any form of income or price support in the sense of Article XVI of GATT 1994" and " $a$ benefit is thereby conferred" (SCM Agreement, art.1.1). The Appellate Body has underlined that "financial contribution" and "benefit" are separate legal elements that are both required to be satisfied in order to constitute a subsidy within the SCM Agreement (Appellate Body Report, Brazil-Aircraft, para.157). Article 1.2 of the SCM Agreement indicates that in order for a subsidy to be actionable, prohibited or subject to countervailing duties, it must be "specific" (SCM Agreement, art.1.2). The criteria to determine whether or not a subsidy shall be deemed "specific" to "an enterprise or industry or group of enterprises or industries" for the purposes of the SCM Agreement are contained in Article 2 (Trebilcock, Howse, \& Eliason, 2012: p.374). The Panel in the present dispute gave a more explicit description of the relationship among "specificity", "financial contribution", and "benefit" - three independent and cumulative elements, all of which must be present for a measure to be covered by the SCM Agreement (Panel Report, US-Anti-Dumping and Countervailing Duties, para.9.29). The Panel also agreed with the approach taken by the panels in EC-Countervailing Measures on DRAM Chips, US-Countervailing Duty Investigation on DRAMS, and Korea-Commercial Vessels, all of which analyzed the question of specificity separately from financial contribution and benefit (Panel Report, US- Anti-Dumping and Countervailing Duties, para.9.29).

As mentioned above, the four countervailing duty investigations conducted by the USDOC covered four products from China, CWP, OTR, LWR, and LWS. Based on the facts available, the USDOC determined that China provided subsidies in the form of preferential lending by SOCBs to several producers such as East Pipe, "GTC", and Starbright. These subsidies were de jure specific. The USDOC also found that the government provision of land-use rights was a countervailable subsidy, and used out-of-country benchmarks to determine the existence and amount of the subsidy benefits (Exhibit CHI-3, pp. 11-21, 49-70 \& 82-83).

\section{Provision of Loans}

\section{Financial Contribution}

As mentioned above, subsidies are subject to the SCM Agreement only if the three elements - financial contribution, benefit, and specificity - are satisfied. With regards to a "financial contribution", there are three types recognized in Article 1.1. These include situations in which a government practice involves a direct transfer of funds (e.g. grants, loans, and equity infusion), or a potential direct transfer of funds or liabilities (e.g. 
loan guarantees), government revenue that is otherwise due is foregone or not collected (e.g. fiscal incentives such as tax credits) and a government provides goods or services other than general infrastructure or purchased goods (Panel Report, USExports Restraints, para.8.69).

Accordingly, the USDOC determined that China's SOCBs are providing preferential loans to the tire industry, which constitute a direct transfer of funds. In the Japan-DRAMs (Korea) decision, the term "funds" in the direct transfer of funds or potential direct transfer of funds or liabilities contemplated in Article 1.1 (a) (1) (i) was interpreted (Trebilcock, Howse, \& Eliason, 2012: p. 368). The Appellate Body indicated that "funds" refers not only to money but also to financial resources and other financial claims (Appellate Body Report, JapanDRAMs (Korea), para.250). The items "grants, loans, and equity infusions" are provided as examples and thus, modifications of loan repayment terms and debt-to-equity swaps as transactions fall within the "direct transfer of funds" contemplated in the Article (Appellate Body Report, Japan-DRAMs (Korea), para.251 \& 256). In this regard, providing loans by SOCBs to the tire industry constitute a "financial contribution" within the meaning of Article 1.1 (a) (1). There is no disagreement between the parties as to the existence of SOCBs lending to the two tire producers. Instead, the disagreement in the context of the de jure specificity finding centers on whether the SOCBs made these loans pursuant to the policies set forth in planning documents.

\section{Benefits}

Regarding a "benefit", the Panel in Korea-Commercial Vessels articulated that it "acts as a screen to filter out commercial conduct" (Panel Report, Korea-Commercial Vessels, p.7.28). Article 1.1 (b) simply provides that "a benefit is thereby conferred (SCM Agreement, art. 1.1 (b))", and does not offer any guidance as to how "benefit" should be defined for the purpose of the SCM Agreement. The Appellate Body in Canada-Civilian Aircraft upheld the Panel's interpretation that in order to confer a "benefit", a financial contribution must "[be provided] on terms that are more advantageous than those that would have been available to the recipient on the market" (Panel Report, Canada Aircraft, paras.9.112 \& 9.113). Also, it indicated that Article 14 (discussed below) is relevant. The Appellate Body added that a "benefit" can only exist where there is a beneficiary or recipient, whether "a person, natural or legal, or a group of persons". Therefore, the evaluation of whether or not a benefit has been conferred is to be made with consideration of the market and the specific recipient (Appellate Body Report, Canada-Aircraft, para.154).

\section{Specificity}

In addition to a "financial contribution" and "benefit", the third element for subsidies to be subject to countervailing duties is "specificity". Article 2 sets out the principles to determine whether or not a subsidy shall be deemed "specific" to "an enterprise or industry or group of enterprises or industries" for the purpose of the SCM Agreement (SCM Agreement, art.2).

Article 2: Specificity

2.1 In order to determine whether a subsidy, as defined in paragraph 1 of Article 1, is specific to an enterprise or industry or group of enterprises or industries (referred to in this Agreement as "certain enterprise") within the jurisdiction of the granting authority, the following principles shall apply: (a) Where the granting authority, or the legislation pursuant to which the granting authority operates, explicitly limits access to a subsidy to certain enterprises, such subsidy shall be specific.

(b) Where the granting authority, or the legislation pursuant to which the granting authority operates, establishes objective criteria or conditions governing the eligibility for, and the amount of, a subsidy, specificity shall not exist, provided that the eligibility is automatic and that such criteria and conditions are strictly adhered to. The criteria or conditions must be clearly spelled out in law, regulation, or other official document, so as to be capable of verification.

(c) If, notwithstanding any appearance of non-specificity resulting from the application of the principles laid down in subparagraphs (a) and (b), there are reasons to believe that the subsidy may in fact be specific, other factors may be considered...

This provision covers specific subsidies which are explicitly only accessible to certain enterprises. Specificity will not exist, if the granting authority, or the legislation, establishes objective criteria or conditions governing the eligibility for and the amount of a subsidy (SCM Agreement, art.2.1 (b)). The objective qualification requirements must be in some official documents for verification purposes (SCM Agreement, art.2.1 (b)).

In the present dispute, the USDOC determined that China provided subsidies in the form of preferential lending by SOCBs (referred to by the USDOC as "policy lending") to the tire industry, in particular to two companies, GTC and Starbright (Exhibit CHI-4, footnote 16). It determined that these subsidies were de jure specific on the basis that relevant Chinese laws, plans and policies explicitly limited access to such "policy lending" by SOCBs to a group of industries that included the tire industry.

The USDOC's finding showed that the various documents identified "certain enterprises", which included the tire industry, for development through the provision of loan financing. For example, at the central government level, the Government of China's Five-Year Plans set the overall economic policies for China; these policies were then implemented in detail through subsidiary central government-level instruments. The USDOC further found that the provincial and local governments implemented national plans and policies at their respective levels (Exhibit CHI-4, p.13 \& 98). The Panel, after analyzing both central and provincial and municipal governments planning documents (including the GOC 11th Five-Year Plan (20062010), the Implementing Regulation of the 11th Five-Year Plan, the GOC Catalogue, the GOC 10th Five-Year Plan (2001-2005), the SETC Circular 716, Guizhou and Guiyang Planning documents, and Heibei planning documents), concluded that the Government of China, at the central level, explicitly identified "certain enterprises" in the sense of Article 2.1 (a) of the SCM Agreement for encouragement and development (including the tire industry), and instructed the sub-central governments to implement this policy. SOCBs (among other financial institutions) were instructed to provide financing to the "encouraged" projects.

After concluding that government authorities at all levels of government in China (central, provincial, and municipal) effectuated policies to ensure the provision of loans to the tire industry, the question is whether SOCBs acted pursuant to the government policies set forth in those planning documents when they provided loans to the tire producers. In the CFS $\mathrm{Pa}$ - 
per investigation, which formed part of the record in the OTR investigation, the USDOC had determined that SOCBs followed government policies in making decisions (Exhibit CHI93: pp. 49-58). The reasons included three aspects: 1) the state ownership of the Chinese banking sector and the legacies associated with the longstanding pursuit of government policy objectives undermined the SOCBs' ability to act on a commercial basis (Exhibit CHI-93, p. 55); 2) the Chinese Commercial Banking Law required banks to carry out their loan activities consistently with "the need of national economy and the social development and under the guidance of State industrial policies" (Exhibit CHI-93, p. 58); 3) although SOCBs were improving their risk management capacities, they still lacked adequate risk management and analysis skills. In addition, the United States also referred to a range of documents including annual reports and other publications of certain Chinese banks, verification reports, and others. In particular, the United States cited the following statements by banks: 1) the People's Bank of China "guided financial institutions to grant loans at a proper pace"; 2) the People's Bank of China briefs bank officers on "how credit should be guided"; 3) the Bank of China takes industrial policies into account "in assessing a company's total credit limit"; and 4) "commercial banks are encouraged to restrict their lending to borrowers in certain industries in accordance with relevant government policies" (United States first written submission, para.358). China does not contest the accuracy of the United States' representations of these statements. Nor does it point to any evidence contradicting the USDOC's conclusion. The Appellate Body believed that the Panel conducted a proper factual analysis based on the totality of evidence, at all levels of government, on which the USDOC supported its specificity determination (Appellate Body Report, US-Anti-Dumping and Countervailing Duties, para.400). The Panel accepted that such documents demonstrate a clear lending policy directed to favour the tire industry. Therefore, the Appellate Body concluded that "China has failed to establish that the USDOC's finding, that lending by SOCBs to the tire industry was de jure specific, was inconsistent with the obligations of the United States under Article 2.1 (a) of the SCM Agreement" (Panel Report, US-Anti-Dumping and Countervailing Duties, para.9.107).

\section{Land-Use Rights}

China challenged the USDOC's determination in the LWS investigation that the provision of land-use rights to one company (Aifudi) located in the "New Century Industrial Park" was regionally specific. In this dispute, the USDOC determined that China's provision of land-use rights to Aifudi constituted a financial contribution by a government in the form of provision of goods or services. According to the USDOC, this financial contribution was de jure specific because the provision of the land-use rights within the Industrial Park was limited to an enterprise or industry located within a designated geographic region. Furthermore, the USDOC added that the land-use rights provided for less than adequate remuneration and therefore conferred a benefit (Exhibit CHI-3, p. 14). The USDOC appeared to focus principally on the process by which the Industrial Park was created, and the irregularities in that process, as well as on how the land-use prices were set both inside and outside the Industrial Park, but with no findings as to any clear basis on which the provision of a financial contribution in the form of land-use rights differed as between land inside and outside the Park. There is no indication in the record evidence that the USDOC examined whether the Park constituted a land-use regime that was clearly distinguished from the general provision of land-use rights by the county government. Therefore, the Panel ruled in favour of China on its claim under Article 2.2, and found that: "The USDOC acted inconsistently with the obligation of the United States under Article 2 of the SCM Agreement by determining that the government provision of land-use rights was regionally-specific" (Panel Report, USAnti-Dumping and Countervailing Duties, para.17.1 (b) (ii) \& 9.161). China appealed this finding not because it did not agree with the Panel's conclusion, but because it disagreed with the basis on which the Panel reached it. China requested the Appellate Body to: 1) find that the Panel erred in interpreting Article 2.2 of the SCM Agreement to permit a finding of specificity based solely on a finding that the financial contribution-rather than the subsidy - was geographically limited; and 2) reverse the Panel's finding that the existence of a "distinct regime" is relevant to a determination of specificity under Article 2.2. The Appellate Body first did not think that the USDOC committed any legal error in basing "its determination of regional specificity on the element of the financial contribution, i.e., on the provision of land-use rights by Huantai County" (Appellate Body Report, US-Anti-Dumping and Countervailing Duties, para.414). Second, the Appellate Body did not find that China has established any relevant error in the Panel's interpretation of the term "subsidy" in Article 2.2, and rejected China's allegation of error in respect of the Panel's statement concerning a "distinct regime" in the context of the investigation (Appellate Body Report, US-Anti-Dumping and Countervailing Duties, para.389).

\section{Conclusions and Recommendations}

The discussion above suggests that there is no simple answer to the question whether China's SOCBs constitute "public bodies".

\section{General}

In the process of the dispute, both parties expressed their opinions on the proper definition of "public bodies" in terms of dictionary definitions, the meaning of the corresponding French and Spanish terms, context, and the object and purpose of the Agreement. China and the United States also referred to some external resources such as the ILC Article, the GATS Financial Services Annex, as well as municipal laws; some relevant WTO cases were also cited to support their arguments. As a result, the Panel agreed with the United States, holding that public bodies are entities controlled by a government. Although the Appellate Body did not accept that majority ownership is sufficient to prove state control, it still found that SOCBs in China are controlled by the government and that they effectively exercise certain governmental functions (Appellate Body Report, USAnti-Dumping and Countervailing Duties, para.355). To explore this issue further, this paper turned to a close examination of the nature of SOCBs in both policy and legal contexts.

Regarding the policy aspect, although SOCBs in China have gone through several stages of transformation from being policy-oriented to benefit-oriented, the Chinese government, represented by the Ministry of Finance and Central Huijin, has 
remained the majority shareholder of SOCBs. However, the influence of the majority state shareholders has been restricted due to the entry of foreign strategic investors in recent years, which could curb undue governmental intervention in business operations of SOCBs. Additionally, SOCBs' social and policy responsibilities have been shifted to the three policy banks since 1995, with a result that SOCBs have become enterprises with profit-making as their top priority.

With respect to the legal aspect, the United States and the Panel advocated that entities controlled by a government are public bodies, but they did not sufficiently demonstrate that state majority ownership could be the single and decisive determinant of "control". Furthermore, the Law of Commercial Banks makes clear that SOCBs are enterprises which prioritize their economic benefits and efficiency ahead of state policies. From the perspective of corporate governance, the Chinese government, as the majority ownership shareholder, could not directly influence the business and operation of SOCBs according to the Company Law, but they have an overwhelming advantage over other shareholders in selecting directors. The selected directors face a dilemma between the benefits of all the shareholders and the appreciation of state assets.

China's SOCBs, according to the theory of governmental control, may constitute "public bodies" within Article 1.1 (a) (1) of the SCM Agreement because of majority state ownership. However, the United States failed to further explain "control" and provide any indicia other than majority ownership. This may weaken the reasoning of the "control" theory. There have been huge changes in China's SOCBs in the past three decades, and it is not easy for them to eliminate their subsidiary governmental function overnight. With the enactment of the Company Law and the Law of Commercial Banks as well as more participation of foreign strategic investors, China's SOCBs are gradually shedding their governmental function and the policy influence of the central government.

The conclusion that SOCBs constitute "public bodies" within the SCM Agreement does not mean that subsidies exist in this present dispute. Subsidies are subject to Article 1 of the SCM Agreement only if the three elements-financial contribution, benefit, and specificity-are satisfied. Various forms of evidence demonstrate that all the three elements are satisfied in terms of SOCBs lending loans to the tire industry; therefore, those loans constitute "subsidies" within the meaning of Article 1.1 (a) (1). However, a financial contribution in the form of land-use rights was not proved in the dispute.

\section{Recommendations}

\section{Policy Flexibility in the WTO System}

There are always trade frictions between different members under the WTO framework, which is partially attributable to their uneven stages of economic development. "The central economic paradox of our time is that 'development economics' is working while 'development policy' is not". To explore this paradox, Dani Rodrik, in his book One Economics, Many Recipes, lays out a broad critique of prevailing approaches to development policy, offers fresh idea for countries seeking to improve their economic performance, and argues for important reforms in the WTO to make room for those ideas (RodríguezClare, 2007, Review of One Economics).

More time and effort are required by developing countries like China to catch up with their developed counterparts. Indeed, according to Rodrik, developing countries may sometimes want to pursue import protection or seek integration with the rest of the world through more heterodox policies such as export subsidies and export-processing zones. The deepening economic integration that has been implemented over the last decade may be detrimental to some poor countries by shrinking the "policy space" they need to follow such policies (Rodríguez-Clare, 2007, Review of One Economics). Instead of sticking to this path, a development friendly WTO should strive for a "better mix of enhanced market access and maneuvering room to pursue appropriate development strategies" (Rodrik, 2008: p. 215). In this regard, a much narrower definition of the term "public bodies" may better promote the participation of developing countries in international trade as well as advance integration with their developed trade partners, since it will give developing countries more time to upgrade their banking sectors and international trade partners to the level required by the WTO system.

\section{Latent Comparative Advantages}

In addition to requesting more flexibility in the WTO system, developing countries should also try to make the best use of their comparative advantages in international trade relations. According to "the new structural economics" proposed by Lifu Lin in his book The Quest for Prosperity, no economy can develop if its firms are not viable in an open, free and competitive market. Therefore, long-term economic development can only be attained if countries rely on market prices and their latent comparative advantages (Lin, 2012: p. 94). For instance, some developing countries have failed in their development goals, because they neglected the fact that they are generally labor-abundant, and their development strategy needs to be based on labor-abundant industries for their firms to be competitive on the world market. Their governments have tried to establish capital-intensive industries that did not match the comparative advantages of the countries, resulting in the fact that these industries were not viable without state invention. Therefore, they required subsidies and other protectionist measures such as tariffs or non-convertible currencies, which lead to the establishment of "a rent-seeking elite and to public expenditure that were not sustainable in the long run" (Lin, 2012: p. 94). Lin argued that the rapid growth of China and other fast-growing East Asian economies were due to the effective exploitation of their latent comparative advantages (Lin, 2012: p. 162). According to Lin, development based on comparative advantage creates job opportunities, ample fiscal revenues, and does not require subsidies for firms; thus, governments have enough policy flexibility to deliver the necessary improvements in both "hard" (power, telecommunications, roads, etc.) and "soft" (education, financial, and legal) infrastructures necessary to support the structural transformation that has to take place continuously for an economy to grow (Lin, 2012: p. 163).

\section{Globalization and State Capitalism}

In order to upgrade their participation in international trade, developing countries need not only more flexibility in the WTO system and more attention to their comparative advantages but also heavy emphasis on the effects of globalization. Rodrik in his later book The Globalization Paradox notes the irony that the countries that experienced the greatest growth during the heyday of the "Washington Consensus" were Japan, China, 
South Korea, and India, which never embraced it. For years, they had nurtured, protected and subsidized key industries before subjecting them to foreign competition. Furthermore, they had closely controlled the allocation of capital and the flow of capital across their borders; they manipulated their currency and maintained formal and informal barriers to imports ("Dani Rodrik's 'The Globalization Paradox"', 2011). It is not easy to reach a compromise between globalization and state capitalism which tries to "meld the powers of the state with the powers of capitalism", and "depends on government to pick winners and promote economic growth" ("The Visible Hands", 2012: p. 3). Peter Mandlson, a former EU trade commissioner, thinks that "the huge and very real benefits of globalization are being undermined by the distorting interventions of state capitalism from one direction and by the anxious politics of an increasingly defensive and fearful developed world from the other". State Capitalism achieved success in tackling infrastructure problems such as building the information superhighway and mandating higher environmental standards. Additionally, it has also been successful at producing national champions that can compete globally. Furthermore, some argue that state capitalism makes it easier for emerging countries to learn from the rest of the world. However, state capitalism has always faced various challenges. There is striking evidence that state-owned companies are not only less innovative but also less productive than their private competitors ("Mixed Bag", 2012: p. 14). In addition, state-capitalist countries harm mainly their consumers when they subsidize exports, and they depress their overall competitiveness when they pour money into state champions at the expense of the rest of the economy ("And the Winner is...", 2012: p. 17). State capitalism's biggest failure is to do with liberty: by turning companies into organs of the government, state capitalism simultaneously concentrates power and corrupts it (“And the Winner is...", 2012: p. 18).

The conflict between state capitalism and globalization will not remain constant and unsolved. State-capitalist countries are also using tools such as listing state-owned companies on the stock market and embracing globalization. Some are keenly working on independent innovation, exemplified by China which revealed its highest priority for the future at the $17^{\text {th }} \mathrm{Na}-$ tional Congress of the Communist Party: improving the country's "capacity for independent innovation". Rodrik addresses that globalization will work for everyone only if "all countries abide by the same set of rules, hammered out and enforced by some form of technocratic global government" ("And the Winner is...", 2012: p. 18). Yet, some countries like China and India are currently reluctant to give up their sovereignty, distinctive institutions and freedom to manage their economies in their own best interests. To some degree, state-capitalism indeed can help those countries wanting to make their mark on the world effectively concentrate their financial resources on developing certain fields like infrastructure. However, it is important to bear in mind that state capitalism can work well in some areas (e.g., infrastructure) and badly in others (e.g., consumer goods); and also, it is possible for it to boost growth at one stage of development and impede it at another ("Mixed Bag", 2012: p. 9). It is not a panacea for all problems plaguing those emerging countries, and it may take many years for the model's weaknesses to become obvious. Indeed, it is not a long-term policy, since no one can escape the challenges of globalization as well as refuse the opportunities offered by it. As Joseph Stiglitz states in his book Making Globalization
Work, globalization has every potential to serve as a force for good (Stiglitz, 2007). In order for globalization to yield economic benefits that are broadly distributed throughout society, national democracies need to be strengthened and international rules need to be in place that protect all players, while still allowing for "maneuverability and flexibility" (Saffin, 2011, "Why Global Markets, States, and Democracy Can't Coexist"). At the same time, the practitioners of state capitalism need to unwind their huge holdings in favor companies and handling them over to private investors ("The Rise of State Capitalism", 2012); this needs to be done slowly but surely.

\section{Conclusion}

It is not easy to strike a balance between global market and state democracy as mentioned above; this is why developing countries should be given more policy room in the WTO system and state capitalism, and also they should pay more attention to their latent comparative advantages. These approaches could help developing countries upgrade their infrastructures, and transform their structure to advance both economic growth and policy development to catch up with their developed counterparts in the future. As a result, they will be able and willing to be guided and bound by international rules. Just as Stiglitz says, "global society has the will and the ability to address global problems, and international economic integration will ultimately prove a force for good". However, this could only be achieved with good will, enlightened public opinion, and moral imperatives to overcome selfish but deeply entrenched private or national interests that do not share the author's goal of making globalization work for as many people as possible (Frienden, 2006, "To Have and Have Not"). Under this circumstance, the whole world will benefit from a concerted effort to address problems of the environment, poverty, and diseases. Globalization, according to some critics, may not be working perfectly today; that is why some structural changes are certainly necessary, especially when it comes to trade - the best way to promote development in poor countries (Wennström, 2006, "Making Globalization Work"). Ensuring that trade is fair is hard when some companies enjoy the support, overt or covert, of a national government. That is why state-capitalist countries should learn how to gradually give up their controllings in state-backed companies, and expose them to competitions or hand them over to private investor. At the same time, international trade institutions should agree to the ending of tariffs and protectionism in the West, and push Third World countries to open up their markets and face external competitions. In this regard, globalization and international trade will be sustainable and prosperous with the consensus from both developing and developed participants on following the agreed international rules and principles.

\section{Acknowledgements}

Grateful thanks to my supervisor Michael Trebilcock from the University of Toronto and Lei Hou from China.

\section{REFERENCES}

Agreement on Implementation of Article VI of the General Agreement on Tariffs and Trade 1994, 15 April 1994, 1868 U.N.T.S. 201 (entered into force 1 January 1995).

Agreement on Subsidies and Countervailing Measures, 15 April 1994, 
1867 U.N.T.S 14 (entered into force 1 January 1995).

And the winner is. (2012). The Economist, 402, 17.

http://www.economist.com/node/21541404

Appellate Body Report, Brazil-Export Financing Programme for Aircraft, WT/DS46/AB/R, adopted 20 August 1999, DSR 1999: III.

Appellate Body Report, Canada-Measures Affecting the Export of Civilian Aircraft, WT/DS70/AB/R, adopted 20 August 1999, DSR 1999: III.

Appellate Body Report, Japan-Countervailing Duties on Dynamic Random Access Memories from Korea, WT/DS336/AB/R and Corr.1, adopted 17 December 2007, DSR 2007: VII.

Appellate Body Report, United States - Countervailing Duties on Certain Corrosion-Resistant Carbon Steel Flat Products from Germany, WT/DS213/AB/R and Corr.1, adopted 19 December 2002.

Appellate Body Report, United States - Countervailing Duty Investigation on Dynamic Random Access Memory Semiconductors (DRAMS) from Korea, WT/DS296/AB/R, adopted 20 July 2005, DSR 2005: XVI, 8131.

Appellate Body Report, United States - Definitive Anti-Dumping and Countervailing Duties on Certain Products from China, WT/DS379/AB/R, adopted 25 March 2011.

Appellate Body Report, United States_Final Countervailing Duty Determination with Respect to Certain Softwood Lumber from Canada, WT/DS257/AB/R, adopted 17 February 2004, DSR 2004: II, 571.

Barboza, D. (2013). A conversation with Carl Walter. The New York Times.

Brown, L. (1993). Shorter Oxford English dictionary (Vols. I, p. 1123 \& II, p. 2404). Oxford: Clarendon Press.

Chanceller, D. (2011). China's fiscal legerdemain. The Wall Street Journal.

http://online.wsj.com/article/SB100014240527487041322045761908 64046071514.html

Chen, Z. Y. (2012). The corporate governance reform of state-owned commercial banks in China. Ph.D. Thesis, Leicester: University of Leicester.

China Development Bank. Mission Statement.

http://www.cdb.com.cn/english/Column.asp?ColumnId=99

China Development Bank. (n.d.).

http://www.cdb.com.cn/english/index.asp

China's economy and the WTO: All change. (2011). The Economist, $401,45$.

China: What will happen in the world's largest nation. Journal of Banking, 33, 113.

Claessens, S. (2002). Corporate governance and development. Washington, DC: Global Corporate Forum.

Company Law of the People's Republic of China (revised in 2005), adopted at the Fifth Session of the Standing Committee of the Eighth National People's Congress on December 29, 1993. Revised for the first time on December 25, 1999 in accordance with the Decision of the Thirteenth Session of the Standing Committee of the Ninth People's Congress on Amending the Company Law of the People's Republic of China. Revised for the second time on August 28, 2004 in accordance with the Decision of the 11th Session of the Standing Committee of the 10th National People's Congress of the People's Republic of China on Amending the Company Law of the People's Republic of China. Revised for the third time at the 18th Session of the 10th National People's Congress of the People's Republic of China on October 27, 2005.

Dami Rodrik's “the globalization paradox”. (2011). The Washington Post.

http://www.washingtonpost.com/wp-dyn/content/article/2011/03/11/ AR2011031106730.html

Draft Articles on the Responsibility of States for Internationally Wrongful Acts, Report of the ILC on the Work of its Fifty-third Session, UN GAOR, 56th Sess, Supp No 10, p. 43, UN Doc A/56/10 (2001).

Duan, K. Y. (2003). Deep reform on SOCBs and research on financial innovation after entry into the WTO. Chengdu: Southwestern University of Finance and Economic Press.

Frienden, J. A. (2006). To have and have not-Book review of making globalization work. The New York Times.

General Agreement on Tariffs and Trade (1994), 15 April 1994, 1867
U.N.T.S 187, 33 I.L.M. 1153 (entered into force 15 January 1995).

Hope, N., \& Hu, F. (2006). Reforming China's banking system: How much can foreign strategic investment help. In J. Aziz, S. Dunaway, \& E. Prasad (Eds.), China and India: Learning from each other, reforms and policies for sustained growth. Washington, DC: IMF Multimedia Services Division.

Huang, K. C. (2009). Perform of China's state owned commercial bank a success. Nomura Journal of Capital Markets, 1, 1.

Industrial \& Commercial Bank. ICBC business review. http://www.icbc.com.cn/ICBC/About\%20Us/Brief\%20Introduction/b rief $\% 20$ introduction $\% 20$ to $\% 20$ icbc.htm

Industrial \& Commercial Bank of China. (n.d.).

http://www.icbc.com.cn/icbc/sy/default.htm

Issues and Decision Memorandum for the Final Affirmative Countervailing Duty Determination: Laminated Woven Sacks from the People's Republic of China, Exhibit CHI-3.

Issues and Decision Memorandum for the Final Determination in the Countervailing Duty Investigation of Coated Free Sheet from the People's Republic of China, Exhibit CHI-93.

Law of the People's Republic of China on Commercial Banks, adopted at the 13th Meeting of the Standing Committee of the Eighth National People's Congress on May 10, 1995, promulgated by Order No. 47 of the President of the People's Republic of China on May 10, 1995, and amended in accordance with the Decision of the Standing Committee of the National People's Congress on Amending the Law of the People's Republic of China on Commercial Banks adopted at the Sixth Meeting of the Standing Committee of the Tenth National People's Congress on December 27, 2003.

Lin, Y. F. (2012). The quest for prosperity: How developing economics can take off. Princeton, NJ: Princeton University Press.

Li, T. (2009). How to deal with the conflict between the system of board of directors and the company Law. Journal of Fujian College of Political Science \& Law, 2, 62.

Li, Y., \& Zhang, Y. M. (2005). The reform of state-owned commercial banks in China. Workshop on reform and development of banking system in China.

Mattoo, A., \& Carzaniga, A. (2003). Moving people to deliver service. Washington, DC: World Bank Publications. http://dx.doi.org/10.1596/0-8213-5406-X

Mixed bag. (2012). The Economist, 402, 14.

New masters of the Universe: State' capitalism's global reach. (2012). The Economist, 402, 6.

Outlaw, J. (2012). Globalization in China. Asian \& the Pacific Zone. http://www.bauerglobalstudies.org/archives/globalization-in-china

Panel Report, Brazil-Export Financing Programme for Aircraft, WT/DS46/R, adopted 20 August 1999, as modified by Appellate Body Report WT/DS46/AB/R, DSR 1999: III, 1221.

Panel Report, Canada-Measures Affecting The Export of Civilian Aircraft, WT/DS70/R, adopted 20 August 1999, upheld by Appellate Body Report WT/DS70/AB/R, DSR 1999: IV.

Panel Report, China-Measures Affecting Trading Rights and Distribution Services for Certain Publications and Audiovisual Entertainment Products, WT/DS363/R and Corr.1, adopted 19 January 2010, as modified by Appellate Body Report WT/DS363/AB/R, DSR 2010: II, 261.

Panel Report, Korea-Measures Affecting Trade in Commercial Vessels, WT/DS273/R, adopted 11 April 2005, DSR 2005: VII.

Panel Report, United States-Definitive Anti-Dumping and Countervailing Duties on Certain Products from China, WT/DS379/R, adopted 25 March 2011, as modified by Appellate Body Report WT/DS379/AB/R.

Panel Report, United States-Measures Treating Exports Restraints as Subsidies, WT/DS194/R and Corr.2, adopted 23 August 2001, DSR 2001: XI, 5767.

Plender, J. (2011). The weakness beneath China's rise-Book review of red capitalism. Financial Times.

http://www.ft.com/intl/cms/s/2/55019600-2caa-11e0-83bd-00144fea b49a.html\#axzz2ckMj9RyC

Prasad, K. (2006). Corporate governance. New Delhi: Prentice-Hall of India Pvt.

Protocol on the Accession of the People's Republic of China, Doha 10 November 2001. 
Ramanadham, V. V. (1993). Privatization: A global perspective. Oxford: Routledge. http://dx.doi.org/10.4324/9780203417294

Responsibility of States for Internationally Wrongful Acts. Text adopted by the ILC at its fifty-third session, in 2001, and submitted to the United Nations General Assembly as a part of the ILC's report covering the work of that session. The General Assembly "[took] note of the articles on responsibility of States for internationally wrongful acts" for the first time in General Assembly Resolution 56/83 of 12 December 2001, corrected by document A/56/49 (Vol. I) / Corr.4, and subsequently in Resolution 59/35 of 2 December 2004, Resolution 62/61 of 6 December 2007, and Resolution 65/19 of 6 December 2010. The ILC's report, which also contains commentaries on the draft articles, appears in the Yearbook of the International Law Commission, 2001, Vol. II, Part Two.

Rodríguez-Clare, A. (2007). Review of one economics, many recipes: Globalization, institutions, and economic growth.

http://emlab.berkeley.edu/ arodeml/Papers/Review\%20of\%20Rodrik 's\%200ne\%20Economics,\%20Many\%20Recipes.pdf

Saffin, K. (2011). Why global markets, states, and democracy can't coexist-Book review of the globalization paradox. The London School of Economic and Political Science.

http://blogs.lse.ac.uk/politicsandpolicy/archives/10284

Song, D. L., \& Liang, Y. Q. (2006). The role and functions of the government in the joint-stock reform of SOCBs in China. Journal of the Staff and Worker's University, 4, 43.

Stevenson, A. (2007). Shorter Oxford English dictionary (6th ed., Vol. 2). Oxford: Oxford University Press.

Stiglitz, J. E. (2007). Making globalization work. New York: W.W. Norton \& Company.

Supervision and Administration of State-Owned Assets of Enterprises Tentative Regulations, promulgated by the State Council on, and effective as of, 27 May 2003.
Taaffe, P. (2011). Book review: Halfway house-Red capitalism: The fragile financial foundation of China's extraordinary rise. Socialism Today.

http://www.socialistalternative.org/news/article11.php?id=1636

Tam, O. K. (2008). Emerging best governance practices in commercial financial institutions: Corporate governance in China's bank. http://www.apec.org.au/docs/08_ALA_RT/S7_Tam.pdf

The rise of state capitalism. (2012). The Economist. http://www.economist.com/node/21543160

The visible hands. (2012). The Economist, 402, 3.

To strength the public-service functions of SOCBs. (2009). Xinhua News. http://news.xinhuanet.com/fortune/2009-08/06/content 11834938.htm

Trebilcock, M. J., Howse, R., \& Eliason, A. (2012). The regulation of international trade. Oxford: Routledge.

United Nations. (1969). Vienna Convention on the Law of Treaties (Vol. 1155, p. 331). 23 May 1969, United Nations, Treaty Series. http://www.refworld.org/docid/3ae6b3a10.html

Usa, I. (2009). China customs, trade regulations and procedures handbook. Washington, DC: International Business Publications.

Usa, I. (2008). China government and business contacts handbook. Washington, DC: International Business Publications.

Walter, C. E., \& Howie, F. J. T. (2010). Red capitalism: The fragile financial foundation of China's extraordinary rise. Singapore: Wiley.

Wennström, J. (2006). Making globalization work. Economic Affairs, 27, 106.

Wen, W. (2010). Ownership structure and bank performance in China: New evidence in China.

http://idem.uab.es/treballs\%20recerca/wen\%20wen.pdf

Zhou, Z. F., \& Li, J. W. (2002). In search of approaches to improving corporate governance in China's state-owned commercial banks. International Lawyer, 36, 215. 